\title{
Şiddetsiz Karşı Koyma Programının Ebeveynlerin Aile İlişkileri ve Ebeveynlik Algıları Üzerindeki Etkisi*
}

\author{
The Effect of Non-Violent Resistance Program on Family \\ Relationships and Parentship Perceptions of Parents
}

\author{
Suat KILIÇARSLAN ${ }^{1}$ Serdal ÖRDEM ${ }^{2}$ Aslı TALTEKINN $^{3}$ Recai ARDIÇ$^{4}$
}

• Geliş Tarihi: 28.05.2018 • Kabul Tarihi: 24.10.2018 • Yayın Tarihi: 01.01.2019

\begin{abstract}
$\ddot{\mathbf{O} z}$
$\mathrm{Bu}$ araştırmanın amacı, ilköğretim ikinci kademede öğrenimlerine devam eden ve saldırgan davranışları olan çocuklara sahip ebeveynlere yönelik uygulanan "Şiddetsiz Karşı Koyma" programının ebeveynlerin aile yapısı, aile etkileşimleri, ebeveyn olarak hissettikleri stres, yetersizlik ve çaresizlik duyguları üzerindeki etkisini incelemektir. Araştırmanın verileri deney ve kontrol grubunda yer alan ebeveynlere uygulanan Aile Değerlendirme Ölçeği ve Öznel Rahatsızlık Birimleri Anketi aracılığıyla elde edilmiştir. Söz konusu ölçekler deney ve kontrol grubu ebeveynlerine öntest, sontest ve izleme ölçümleri olarak uygulanmıştır. Araştırma sonuçları, ebeveynlere uygulanan programın aile içi ilişkilerinde ve etkileşim biçimlerinde pozitif yönde anlamlı değişiklikler meydana getirdiğini; bununla birlikte ebeveynlerin yaşamış oldukları stres, yetersizlik ve çaresizlik duyguları ile baş etme düzeyleri üzerinde pozitif yönde anlamlı farklılık oluşturduğunu göstermiştir. $\mathrm{Bu}$ sonuçlar 1şığında alanda çalışan psikolojik danışman ve araştırmacıların 'Şiddetsiz Karşı Koyma' ebeveyn programını çocuk ve ergenlerde görülen şiddet ve saldırgan davranışlarla ebeveynlerin baş etmesi ve aile ilişkilerinin geliştirilmesi konusunda kullanmalarının yararlı olacağı düşünülmektedir.
\end{abstract}

Anahtar sözcükler: şiddet, saldırganlık, aile ilişkileri, ebeveyn yetersizliği, şiddetsiz karşı koyma.

\section{Önerilen Atıf Bilgisi:}

Kılıçarslan, S., Ördem, S., Taltekin, A.ve Ardıç, A. (2019). Şiddetsiz karşı koyma programının aile ilişkileri ve ebeveynlik algıları üzerindeki etkisi. Pamukkale Üniversitesi Ĕ̆itim Fakültesi Dergisi, 45, 211-234.

\footnotetext{
*Bu makale 2016 yılında tamamlanan, 2015-1-TR01-KA101-016961 sözleşme numaralı "Şiddetsiz Karş1 Koyma" isimli Erasmus+ projesi çerçevesinde yapılan çalışmaların bir ürünüdür ve Türkiye Ulusal Ajansı tarafindan desteklenmiştir.

*Bu makale, 1-3 Aralık 2016 tarihinde Gaziantep'te düzenlenen VI. Ulusal PDR Uygulamaları Kongresinde özet sözlü bildiri olarak sunulmuştur.

${ }^{1}$ Niğde, Ömer Halisdemir Üniversitesi, Eğitim Fakültesi, Eğitim Bilimleri Bölümü ORCID: 0000-00022907-8480, suatkilicarslan@ ohu.edu.tr,

${ }^{2}$ Adana Akkapı Mesleki Teknik ve Anadolu Lisesi, ORCID: 0000-0002-5935-2145, serden7@gmail.com

${ }^{3}$ Adana Vehbi Güzel Mesleki ve Teknik Anadolu Lisesi, ORCID:0000-0001-7898-719X ataltekin@gmail.com

${ }^{4}$ Adana Akkapı Mesleki Teknik ve Anadolu Lisesi, ORCID: 0000-0002-6944-8685, recaiardic@hotmail.com
} 


\begin{abstract}
The aim of this study is to examine the Non-violent Resistance program which is applied to the parents of the children in secondary level education and show aggressive behavior and its effects of on the family structure of the parents and their interactions, the stress they experienced, the inadequacy they felt, and the feelings of helplessness. The data of the study were obtained through the 'Family Assessment Scale' and "Subjective Units of Disturbance Scale" applied to the parents in the experimental and control groups. These scales were applied to the parents of the experimental and control groups as pre-test, post-test and follow-up measurements. When the results of the study were examined, it was seen that the program applied to the parents causes significant changes in the positive direction on the forms of interaction within the family, and it is seen that the parents have a meaningful difference on the levels of coping with the feelings of stress, disability and helplessness. According to these results it is considered that it will be beneficiary for the psychological counselors and researchers working in this area to apply Non Violent Resistance program to deal with violence and aggressive behavior in children and adolescents and to develop family relations.
\end{abstract}

Keywords: violence, aggression, family relationships, parental inadequacy, support, non-violent resistance program.

\title{
Giriş
}

İçinde bulunduğumuz yüzyılda eğitim ve teknolojideki değişimler, çok kültürlülük ve küreselleşme toplumları ve bireyleri, en çok da çocuk ve ergenleri derinden etkilemektedir. Sosyo-kültürel yapılardaki farklılaşma çocuk ve ergenlerin sağlıssız tutum ve davranışlar ortaya çıkarmasına sebep olabilmektedir. Yaşamış olduğu gerilim ve çatışmalarla baş edemeyen çocuklar zaman zaman şiddet ve saldırganlık içeren tutum ve davranışlar sergilemektedir. Dünya Sağlık Örgütü (2002) şiddeti, "Bireyin kendisine, diğer bir kişiye ya da grup veya topluluğa yaralanma, ölüm, psikolojik zarar, yoksunluk ya da gelişim bozukluğuna yol açacak ya da yol açma olasıllğı yüksek olacak şekilde, kasitlı olarak fiziksel güç ya da kudret uygulamasi ya da bununla tehdit etmesi" olarak tanımlamaktadır.

Şiddet davranışları gösterme, çocuğun kendisini güvende hissetmek için yöneldiği bir başa çıkma mekanizması olabilmekte ve saldırgan davranışları normalleştirmeye yönelik zihinsel stratejilerin kullanımıyla sorun daha kalıcı hale gelebilmektedir. Genç bireylerde görülen şiddetin nedenlerini araştıran çalışmalar, aile içinde ya da sosyal ortamlarda şiddete maruz kalmanın veya şahit olmanın çocuk ve ergenlerin gelişimini olumsuz etkilediğini ve güven duygusu zedelediğini vurgulamaktadır (Salzinger, Feldman ve Hood, 2002).

Şiddet ve saldırganlık dünyanın her yerinde olduğu gibi Türkiye'de de çok ciddi bir toplumsal problem haline gelmiştir. Sosyal ortamlarda şiddet içeren olaylardaki artışın okul çağ çocuk ve gençlerini de içine alacak şekilde yaygınlaşması önleme ve müdahale hizmetlerinin artırılmasını zorunlu kılmaktadır (Bacıoğlu, 2014). Alan yazın incelendiğinde, şiddet kullanan çocuk ve ergenlerin arkadaşlık ilişkisi kurmakta zorlandığı, yakın ilişkilerde güvensizlik hissettikleri ve ilişkileri konusunda karamsar oldukları görülmüştür (Levendosky, Huth-Bocks ve Semel, 2002). Saldırganca ve şiddet içeren davranışlar, evrensel düzeyde günümüz toplumlarının en önemli sorunlarından biri olarak karşımıza çıkmaktadır ve bireyin psikolojik ve fizyolojik durumuyla ilişkili olduğu kadar, içinde yaşanılan toplumsal ve kültürel dinamiklerle de ilişkilendirilmektedir (Hassan, Osman ve Azarian, 2009). Çocuk ve ergenlerde görülen şiddet davranışlarını önlemeye yönelik son yıllarda yapılan deneysel araştırmaların etkisinin incelendiği meta-analitik çalışmalar, öğrenci ve ailelere yönelik önleme ve müdahale programlarının saldırganlık ve şiddet davranışlarını azaltmada, ebeveyn çocuk ilişkilerini ve aile ilişkilerinin geliştirilmesi konusunda pozitif yönde anlamlı sonuçlar sağladığını göstermiştir (Wilson ve Mark, 2007; Şahin ve Kalburan, 2009; Bacığlu, 2014; Omer ve Lebowitz, 2016). 
Şiddetsiz Karşı Koyma Programının Ebeveynlerin Aile İlişkileri ve Ebeveynlik Algıları Üzerindeki Etkisi

Türkiye'de çocuk ve ergenlerde görülen şiddet ve saldırganlıkla baş etmeye yönelik pek çok aile programı olduğu görülmektedir. Uygulanan ebeveyn programlarının etkisi incelendiğinde, anne-babaların ebeveynlik becerilerinin arttığı (Pehlivan, 2008; Yıldız, 2003); ebeveyn olarak yaşadıkları stres düzeylerinin azaldığı (Çekiç, 2015), eğitimi programına katılan anne-babaların çocuklarının davranış sorunlarının anlamlı düzeyde azaldığı (Kaymak-Özmen, 2013); çocukları ile olan ilişkilerinin pozitif yönde gelişme gösterdiği (Bal ve Bedel, 2015; Kabasakal, 2013; Kocayürek ve Sümer, 2009; Akgün, 2008); anne-baba ve çocuk arasındaki gerginliğin azaldığı, aile etkileşim tarzları ve aile üyeleri arasındaki ilişkilerin pozitif yönde farklılaştı̆ı (Yeşilleten, 2001; Özdemir, 1991) belirlenmiştir.

Alanyazın incelendiğinde, şiddet içeren davranışlara sahip çocuklar için önleme ve müdahale programlarının daha çok ebeveynlere yönelik yapıldığı görülmüştür (Kotchick, Shaffer, Dorsey ve Forehand, 2004). Çocuk ve ergenlerde görülen şiddet problemi ile baş etmek konusunda anne babaların ebeveynlik becerilerinin artırılmasına yönelik sistemik yaklaşıma dayalı olarak geliştirilmiş olan Şiddetsiz Karşı Koyma modelinin aile ve okul ortamlarında uygulanması hızla yaygınlaşmaktadır (Omer ve Lebowitz, 2016).

Şiddetsiz Karşı Koyma (Non-violent resistance-NVR) ebeveynlerin umutsuzluk, izolasyon ve çocuklarıyla karşılıklı olarak gerilimi arttıran etkileşimleriyle etkili biçimde başa çıkmalarına yardımcı olmayı hedefleyen yeni bir yaklaşımdır (Weinblatt ve Omer, 2008). NVR'yi şiddet içeren davranış sorunlarına sahip çocukların ebeveynleri ile kullanmanın gerekçesi ebeveynlerin yaşadığı çaresizlik ve yetersizlik duyguları ile ilgilidir. NVR, şiddet ve kendine zarar verici davranışlarla baş etmek için gerginliği tırmandırmayan ve kesinlikle şiddet içermeyen yöntemlerle ebeveynlere, öğretmenlere ve diğer bakım veren kişilere yardımcı olmak için oluşturulmuştur (Omer, 2001, 2004). Şiddet içeren davranış sorunları olan çocukların ebeveynleri sıklıkla kendilerini çocuklardan daha az güce sahip olarak görürler (Bugental ve Lewis, 1998), müdahale etmek için yaptıklarının işe yaramayacağını düşünürler ve iş çocuklarının talepleri ile baş etmeye veya çatışmalara geldiğinde kendilerini önceden mağlup olarak hissederler (Webster-Stratton ve Herbert, 1994). Bazı anne babalar cezalandırıcı davranarak ve şiddete başvurarak öfkelerine yenilir (Forgatch, 1991); bazıları ise çocuklarının taleplerine boyun eğer (Baumrind, 1991). Ĕger ebeveynleri açık kurallar ve sınırlar koyamaz, çocuklarının yaptıklarını denetleyemezlerse çocuklarda görülen şiddet içeren davranış sorunlarının artma riskinin yüksek olduğu tespit edilmiştir (Bates, Petit, Dodge ve Ridge, 1998; Florsheim, Tolan ve Gorman-Smith, 1998; Steinberg, 1987; Wilson, 1987).

Omer (2008), özgür ve çoğulcu bir toplumda kabul edilebilir ve uygulanabilir olan bir ebeveyn otoritesi fikrini ortaya atmıştır. En büyük önermesi; geleneksel otoritenin bir zamanlar bildiğimiz gibi, onu mümkün kılan sosyal ve kültürel desteklerden yoksun olduğu için artık kabul edilebilir ve uygulanabilir olmadığıdır. Otoritenin geleneksel modelinin çöküşü ve tamamen özgür eğitim hayalinin başarısızlığı ebeveynlerde bir ikilem oluşturmaktadır; kabul gören, kullanışlı ve toplumumuz tarafindan el üstünde tutulan çoğulculuk ve bağımsızlık değerleri ile uyumlu bir otorite şekli nasıl geliştirebilir? Bu ihtiyaçlardan hareketle Şiddetsiz Karşı Koyma modeli çocuk ve ergenlerde görülen şiddet davranışları ile baş etmede ebeveyn, eğitimci ve bakım veren kişiler için geliştirilmiştir. 
$\mathrm{Bu}$ araştırmada şiddet ve saldırganlık, sadece çocuğun yaşadığı bir sorun olarak değil, aynı zamanda aile ilişkileri, aile üyeleri arasındaki etkileşim biçimleri ve ailenin de içinde bulunduğu toplumsal ve kültürel bir yapı sorunu olarak ele alınmıştır. Araştırmada ebeveynler tarafından en çok yakınılan problemler arasında çocuklarının sözlü ve fiziksel şiddet davranışları göstermesi, evde ve okulda kurallara uymama gibi ciddi disiplin problemleri, çalma davranış1, okula gitmeme, okuldan veya evden kaçma tehditlerini içeren duygusal şantajlar bulunmaktadır. Araştırmaya katılan ebeveynlerin çocukları şiddet davranışları ile ilgili herhangi bir psikiyatrik tanı almamışlardır, ancak program öncesinde yapılan öngörüşmelerde ebeveynler, evde ve okulda çocuklarının gösterdiği istenmeyen bu davranışlarla baş etmekte çok güçlük çektiklerini ve yardıma ihtiyaç duyduklarını ifade etmişlerdir. Bu doğrultuda annebabaların okulda ve evde çocuklarının arkadaşlarına, kardeşlerine ve kendilerine yönelik göstermiş oldukları şiddet davranışları ile baş etme ve ebeveynlik becerilerinin geliştirilmesi amacıyla, aile yapısı ve etkileşimlerinde değişiklik yapmayı hedef alan farklı aile eğitim programlarına ihtiyaç olduğu düşünülmektedir.

Şiddet içeren davranış problemleri Türkiye'de ve dünyadaki önemli toplumsal problemlerdendir (McAdams, \& Lambie, 2003; Pişkin, 2010; Uzbaş ve Topçu Kabasakal, 2009). Bu sorunun erken ve etkin bir biçimde çözülebilmesi için önleme ve müdahale çalışmalarına ihtiyaç duyulmaktadır. Bu bağlamda çocuk ve ergenlere yönelik uygulanan okul temelli önleme programlarının yanı sıra, şiddet ve saldırganlık içeren davranışlara sahip çocukları olan anne-babaların aile içi etkileşim ve ebeveynlik becerilerinin geliştirilmesine yönelik destek programlarının çok önemli olduğu düşünülmektedir.

Diğer aile eğitim programlarından farklı olarak sistemik aile terapisi yaklaşımına dayalı olarak geliştirilen NVR programının uygulandığı çalışmalar Türkiye'de çok sınırlı sayıda olmakla birlikte (Kılıçarslan, 2016), program yurt dışında pek çok farklı kültürde ve popülasyonda uygulanmıştır. Yurt dışında yapılan çalışmalar incelendiğinde; programın ebeveyn ve çocuk arasındaki gerginliği azalttığ ve mağdur olan kardeşlere koruma sağladığ 1 (Omer, Schorr-Sapir ve Weinblatt, 2008), ebeveynlerdeki izolasyon, çaresizlik ve gerginliği artırıcı davranışların azaldığı, algılanmış sosyal desteğin arttığı ve gençlerin dışa vuran şiddet davranışlarında anlamlı düzeyde azalma olduğu (Weinblatt ve Omer, 2008), aile içinde gerginliğin azaldığı ve ebeveynlerin çocuklarına yönelik koşulsuz sevgi eylemlerinin arttığ (Newman, Fagan ve Webb, 2014), ebeveynlerin çaresizlik duygularının azaldığı, ebeveyn-çocuk gerginlik tırmanması, güç mücadeleleri ve ebeveynsel boyun eğmede pozitif yönde iyileşmeler görüldügü (Lavi-Levavi, Shachar ve Ömer, 2013), ebeveynlerin sosyal destek kullanımının daha fazla arttığı (Van Holen ve diğerleri (2015) görülmüştür.

Müdahale programı, ebeveynlerle yürütülmesine rağmen, sistemik aile terapine dayalı temel bakış açısı çerçevesinde hem ebeveynler hem de çocuk üzerine yoğunlaşmaktadır (Omer, Steinmetz, Carthy ve Schlippe, 2013). Sistemik aile terapisi yaklaşımına göre bireyin davranışlarının tam olarak anlaşılması için kişi içinde bulunduğu aile sisteminin ilişkilerinin bütünlügü çerçevesinde ele alınır ve aile üyeleri arasında karşılıklı etkileşim ortaya çıkarılmaya çalışı1ır. Ailenin her bir üyesinin gelişimi ve davranışı, diğer üyeler ile çok yakından ilişkilidir. Problem davranışlar genellikle ailedeki yerleşik ilişki kalıplarının dışa yansıması olarak değerlendirilmektedir. Aile sistemi yaklaşımına göre, birey içinde yaşadığı sisteme bağlıdır ve problem davranışlar konusunda değişimin sağlanması, aileyi ya da ilişkiyi bir bütün olarak ele 
Şiddetsiz Karşı Koyma Programının Ebeveynlerin Aile İlişkileri ve Ebeveynlik Algıları Üzerindeki Etkisi

alarak mümkün olabilmektedir. Bu açıdan müdahalenin yalnız sorunlu bireyle sınırlı kalmaması, ailenin tüm bireylerine uygulanacak şekilde kapsamlı olarak ele alınması gerektiği ortaya çıkmaktadır (Becvar ve Becvar, 2003).

$\mathrm{Bu}$ araştırmada ebeveynlere uygulanan 'Şiddetsiz Karşı Koyma' programı çerçevesinde sadece şiddet davranışları olan çocuk ve ergenler üzerine odaklanılmamakta; bununla birlikte anne-babaların ebeveynlik becerileri ve zarar görmüş olan aile ilişkilerinin onarılması üzerinde durularak, ebeveynlere yeni bir bakış açısı kazandırılması hedeflenmiştir. $\mathrm{Bu}$ bilgiler doğrultusunda bu araştırmanın amacı, şiddet içeren tutum ve davranışlara sahip çocukları olan ebeveynlere uygulanan 'Şiddetsiz Karşı Koyma' programının ebeveynlerin aile yapısı ve etkileşimleri, yaşadıkları stres, ebeveyn olarak hissettikleri yetersizlik ve çaresizlik duyguları üzerindeki etkisini incelemektir. Araştırmada, probleme dayalı olarak 'Şiddetsiz Karşı Koyma' programının etkililiğine ilişkin geliştirilen denenceler aşağıda yer almaktadır.

Denence 1: 'Şiddetsiz Karşı Koyma' programının uygulandığ 1 deney grubu ebeveynlerinin kontrol grubu ebeveynlerine göre 'Aile Değerlendirme Ölçeği' toplam puanı ve alt ölçeklerinden aldıkları sontest puanları öntest puanlarından anlamlı düzeyde düşüktür ve bu fark izleme ölçümünde de devam etmektedir.

Denence 2: 'Şiddetsiz Karşı Koyma' programının uygulandığı deney grubu ebeveynlerinin kontrol grubu ebeveynlerine göre ‘Öznel Rahatsızlık Birimleri Anketi - Stresle Baş Etme' alt boyutu sontest ve izleme testi puanları öntest puanlarından anlamlı düzeyde yüksektir.

Denence 3: 'Şiddetsiz Karşı Koyma' programının uygulandığı deney grubu ebeveynlerinin kontrol grubu ebeveynlerine göre 'Öznel Rahatsızlık Birimleri Anketi - Yetersizlikle Baş Etme' alt boyutu sontest ve izleme testi puanları öntest puanlarından anlamlı düzeyde yüksektir.

Denence 4: 'Şiddetsiz Karşı Koyma' programının uygulandığı deney grubu ebeveynlerinin kontrol grubu ebeveynlerine göre 'Öznel Rahatsızlık Birimleri Anketi - Çaresizlikle Baş Etme' alt boyutu sontest ve izleme testi puanları öntest puanlarından anlamlı düzeyde yüksektir.

\section{Yöntem}

\section{Araştırmanın Modeli}

$\mathrm{Bu}$ araştırma yar1-deneysel desende olup, araştırmada deneysel desen türlerinden biri olan "öntest-sontest kontrol gruplu deneysel model” kullanılmıştır. Gerçek deneme modellerinin gerektirdiği kontrollerin sağlanamadığı durumlarda yarı-deneme modellerinden yararlanılır (Karasar, 2004). Bu desen deney ve kontrol gruplarının eşitlenmesi işleminde kontrolü sağlamaya yardım ederken, deneysel işlemin etkililiğini değerlendirmede deneklerin, öntestsontest ölçümleri arasındaki farkları temel alarak yapılan deneysel işlemin etkisinin daha duyarlı bir şekilde incelenebilmesine olanak sağlamaktadır (Robson, 1993). Yarı deneysel çalışmalarda katılımcıların çalışma gruplarına tesadüfi olarak atanması oldukça güçtür ve bağımlı değişken dışında bazı değişkenlerin etki altına alınması gerekebilmektedir (Heppner, Wampold ve Kivlighan, 2013). Bu çerçevede bu araştırmada uygulanan grup eğitim çalışmaları devamlılık gerektirdiğinden ve sadece annelerin oturumlara süreklilik içeren bir şekilde katılabileceklerini belirtmesi sebebiyle cinsiyete göre yansız atama yapılamamıştır; bu yüzden deney ve kontrol grupları annelerden oluşmuştur. Ekonomik gelir düzeyi açısından birbirine yakın gelir düzeyine sahip ailelerin çalışma gruplara katılımı sağlanmasına özen gösterilmiş, bununla birlikte gruplar 
oluşturulurken çocukların ve ebeveynlerin herhangi bir psikiyatrik tanı almamış olması gibi değişkenler dikkate alınmıştır.

\section{Çalışma Grubu}

Araştırmanın çalışma grubu, Adana'da bir ortaokulda 2016-2017 eğitim-öğretim yılında öğrenimlerine devam eden ve okul içinde şiddet ve saldırganlık içeren davranış sorunları olan öğrencilerin ebeveynlerinden oluşmuştur. Proje kapsamında okul idareci ve öğretmenleri ile iletişim kurularak uygulama yapmak için gerekli yasal izinler alınmıştır. Okul içinde şiddet içeren davranış sorunları sebebiyle sınıf öğretmenleri ve okul idarecileri tarafından okul psikolojik danışma ve rehberlik servisine yönlendirilen öğrencilerin ebeveynleri ile okul içerisinde çalışma öncesi değerlendirme toplantısı yapılmıştır. Bu kapsamda araştırmaya katılmaya gönüllü ebeveynler arasından 28 ebeveyn (14 deney-14 Kontrol) deney ve kontrol gruplarına atanmıştır.

\section{Veri Toplama Araçları}

\section{Aile Değerlendirme Ölçeği (ADÖ)}

Aile Değerlendirme Ölçeği (McMaster Family Assesment Device) Amerika Birleşik Devletleri'nde (ABD) Epstein, Bolwin ve Bishop (1983), tarafından aile işlevlerini çeşitli boyutlarda ölçmek üzere geliştirilmiştir. Ölçeğin Türkiye'de uyarlama çalışması Bulut (1990), tarafından yapılmıştır. On iki yaş üzerindeki tüm aile üyelerine ve katılımcının kendisine aile işlevlerini değerlendirmek amacıyla uygulanabilmektedir. Problem Çözme (PRÇ), İletişim (ILLT), Roller (ROL), Duygusal Tepki Verebilme (DTV), Gereken İlgiyi Gösterme (GİG), Davranış Kontrolü (DVK) ve Genel Fonksiyonlar (GNF) adı altında 7 alt ölçekten oluşan Aile Değerlendirme Ölçeği toplam 60 maddedir. Ölçek "Aynen katılıyorum" (1 puan) ile "Hiç katılmıyorum" (4 puan) arasında değişen dört noktalı bir derecelendirme üzerinden puanlanmaktadır. Ölçekte 35 madde ters puanlanmaktadır. Yüksek puan bireyin o işlev açısından sağlıksızlığının arttığını göstermektedir. Alt ölçeklerin Cronbach Alfa katsayıları 0.38 ile 0.86 arasında değişmektedir (Bulut, 1990).

\section{Öznel Rahatsızlık Birimleri (Subjective Units of Disturbance Scale - SUDS) Anketi}

Öznel Rahatsızlık Birimleri Anketi (SUDS) Joseph Wolpe tarafindan 1969 yılında geliştirilmiştir. Wolpe, "SUDS" anketini insanlara kendi rahatsızlık seviyelerini endişeli ve korkulu hissettikleri belirli durumlarda 0 ile 10 arasında bir derecelendirme üzerinde belirlemeye yardım etmek için kullanmıştır. SUDS anketi, bu araştırmada ebeveynlere program süresi ve sonrasında ebeveynlik becerilerine yönelik hissettikleri yetersizlikle baş etme, çaresizlikle baş etme ve stres düzeyi ile baş etmeye yönelik temel algilarında bir şeylerin değiştiğini hissedip hissetmediklerini değerlendirmeleri amaciyla bir derecelendirme anketi olarak kullanılmıştır. Öznel Rahatsızlık Birimleri Ölçeği, hem klinik hem de araştırma uygulamalarında, özellikle davranış terapisi alanında yaygın olarak kullanılmaktadır (Kim, Bae ve Chon Park, 2008; Kaplan, Smith ve Coons, 1995).

\section{Şiddetsiz Karşı Koyma Programı (Non-Violent Resistance Program-NVR)}

$\mathrm{Bu}$ araştırma kapsamında şiddet ve saldırganlık davranışları olan öğrencilerin ebeveynlerinden oluşan deney grubuna, ortalama doksan dakikadan oluşan 14 oturumluk Şiddetsiz Karşı Koyma (NVR) ebeveyn programı (Day ve Heismann, 2010) uygulanmıştır. Program, öncelikle ebeveyn 
Şiddetsiz Karşı Koyma Programının Ebeveynlerin Aile İlişkileri ve Ebeveynlik Algıları Üzerindeki Etkisi

olarak yetersizlik ve çaresizlik yaşayan ve çocuklarıyla ilgili problemlerde gerginliğe kapılan anne-babalara yardım etmek, geri kışkırtma ya da şiddete teslim olmaksızın çocuğun saldırgan ve kendine zarar verici davranışlarına etkili bir şekilde karşı koymayı öğretmeyi hedeflemektedir. Müdahale programı, ebeveynlerle yürütülmesine rağmen, bütüncül bakış açısı çerçevesinde hem ebeveynlik becerileri hem de çocuğun şiddet davranışları üzerine yoğunlaşmaktadır (Omer, Steinmetz, Carthy ve Schlippe, 2013). NVR ebeveyn eğitimi programının, çocuklarının şiddet, kendine zarar verebilecek aktiviteler, okuldan kaçma ve diğer disiplin problemleri ile baş etmeye yardım etmek amacıyla anne-babalar için tasarlanmıştır (Omer, 2004, 2011). NVR, yetişkin bireyler olarak ebeveynlerin çocuklarının davranışlarını değil, sadece kendi davranışlarını değiştirebileceği temel ilkesine göre hareket etmesi gerektiğini düşünür ve çocuklarının olumsuz davranışlarını kontrol etmektense, bu davranışlarla aktif ve şiddet içermeyen bir biçimde mücadele etmeyi amaçlayan bir bakış açısına sahiptir (Omer ve Lebovitz, 2016).

Programın ana hatları incelendiğinde, öncelikle program hakkında detaylı bilgi verildiği ve ebeveynlerin programa uygunluğunun tartışıldığı ön değerlendirme oturumu, on oturumluk beceri eğitimleri (1. Gerginlik artışı ile baş etme, 2. Ev içinde ebeveyn varlığının hissedilmesi, 3. Ebeveynlere yaşadıkları problemleri önceliklendirme becerisi kazandıran üç sepet tekniği, 4. Destekleyiciler ve destek sistemleri oluşturma, 5. Ebeveynlerin kendi sesini şiddet kullanmadan duyurma becerisi kazanma, 6. Ebeveyn değerleri ve uzlaşma eylemlerinin geliştirilmesi, 7. Şiddete karşı aktif direnç geliştirme, 8. Çocukla çatışma içine girmeden aktif direnç göstermeyi temsil eden oturma eylemi yapma, 9. Ev dışında ebeveyn varlığının geliştirilmesi, 10. Özet ve değerlendirme ve destekleyici üç oturumdan (1: Duyuru/İlan Etme, 2. Oturma eylemi, 3. Kendine iyi bakma) oluşmaktadır.

Ebeveynlere uygulanan programın (NVR) pilot uygulaması aynı eğitim-öğretim yılı içerisinde araştırma grubu tarafından uygulama yapılan okulda eğitim gören farklı öğrencilerin ebeveynlerinden oluşan gönüllü on ebeveyn ile yapılmıştır. Sonuç olarak, programlarda yer alan tüm etkinlikler bu uygulamada denenmiş ve bazı etkinliklerde, programının başka bir kültürden çevrilmesi sebebiyle kültürümüze uygunluğu bakımından araştırma ekibi tarafindan değerlendirilmiştir. Programda yer alan etkinliklerin Türk kültür ve geleneklerine uygun olarak aile yapısı ve dinamiğine yönelik hassasiyetleri temel alınarak, zamanlama, uygulanışı ve amaca uygunluğu açısından alanında uzman bir akademisyene danışarak araştırma grubu tarafından gerekli düzenlemeler yapılmıştır.

\section{Deneysel İşlem}

$\mathrm{Bu}$ araştırma, Türkiye Ulusal Ajansının desteklemiş olduğu "Şiddetsiz Karşı Koyma" isimli Erasmus ${ }^{+}$proje çerçevesinde 2015-2016 eğitim öğretim yılında Adana/Seyhan ilçesinde bulunan bir ortaokulda yapılmıştır. Proje kapsamında ebeveynlere uygulanan 'Şiddetsiz Karş1 Koyma' programı 14 oturumluk eğitim ve uygulama sürecini kapsamaktadır. Program deney grubuna katılan ebeveynlerle haftada iki kez, yaklaşı 90 dakikalık oturumlar halinde yürütülmüştür. Eğitim uygulamaları araştırma ekibi tarafından, ebeveynlerin isteği çerçevesinde çocuklarının devam ettiği okuldaki toplantı salonunda yapılmıştır. Uygulamalar okul yönetiminin desteği ile katılımcıların daire biçiminde rahatça oturabilecekleri ve etkinliklerin yapılmasına olanak verecek bir ortam hazırlanarak yürütülmüştür. Ebeveyn oturumları, 
etkinlikler hakkında kısa sunumlar, ısınma oyunları, küçük ve büyük grup aktiviteleri, bireysel deneyimlere dair bireysel ve grup paylaşımları ve tartışmalar şeklinde tasarlanmıştır. Programın içerdiği etkinliklerin, pilot uygulamalarla benzer sıra ve süre ile uygulanmasına özen gösterilmiştir. Ebeveyn programının küçük grup aktivitelerini içermesinden dolayı, tüm süreç bir lider uygulayıcı ve üç de yardımcı lider uygulayıcı ile birlikte yürütülmüştür.

\section{Verilerin Analizi}

$\mathrm{Bu}$ araştırma kapsamında ebeveynlerin aile içi ilişkilerini ve etkileşim biçimlerini değerlendirmek için 'Aile Değerlendirme Ölçeği', bununla birlikte ebeveynlerin hissettikleri yetersizlik, çaresizlik ve stres algılarını ortaya çıkarabilmek için de Öznel Rahatsızlık Birimleri Anketi (SUDS) uygulanmıştır. Söz konusu ölçekler deney ve kontrol grubu ebeveynlerine öntest, sontest ve izleme ölçümleri olarak uygulanmıştır. Araştırma verilerinin analizinde aile değerlendirme ölçeği sonuçları için SPSS 22 paket programı kullanılmıştır. Verilerin analizi sürecinde parametrik testlerin varsayımları sağlanamadığı için, nonparametrik testlerden Mann Whitney U testi ve Wilcoxon İşaretli Sıralar Testi kullanılmıştır. İzleme ölçümü ise sontest ölçümlerinin bitiminden üç ay sonra deney ve kontrol grubunda bulunan ebeveynlerden alınmıştır. Öznel rahatsızlık birimleri anket verileri için ise katılımcıların öntest, sontest ve izleme ölçümlerinden almış oldukları puanları içerik analizi yapılarak, frekans, yüzdelik değer ve puan ortalamaları grafiği ile karşılaştırmalı olarak incelenmiştir. Verilerin analizi aşamasında ilk olarak deney ve kontrol grubuna atanan ebeveynlerin Aile değerlendirme ölçeği toplam puanı ve alt ölçekleri öntest puan ortalamaları arasındaki farka Mann Withney U testi ile bakılmış ve sonuçlar Tablo 1 'te sunulmuştur.

Tablo 1. Deney ve Kontrol Gruplarının Aile Değerlendirme Öıçeği Toplam Puanı ve Alt Ölçekleri Öntest Puanlarına İlişkin Mann Whitney U Testi Sonuçları

\begin{tabular}{|c|c|c|c|c|c|c|}
\hline Ölçüm & Gruplar & $\mathrm{n}$ & Sira Ortalamas1 & Sira Toplamı & $\mathrm{U}$ & $\mathrm{p}$ \\
\hline \multirow[t]{2}{*}{ ADÖ } & Deney & 14 & 12.43 & 174.00 & \multirow[t]{2}{*}{69.00} & \multirow[t]{2}{*}{.182} \\
\hline & Kontrol & 14 & 16.57 & 232.00 & & \\
\hline \multirow[t]{2}{*}{ Problem çözme } & Deney & 14 & 16.04 & 224.50 & \multirow[t]{2}{*}{76.50} & \multirow[t]{2}{*}{.316} \\
\hline & Kontrol & 14 & 12.96 & 181.50 & & \\
\hline \multirow[t]{2}{*}{ İletişim } & Deney & 14 & 12.36 & 173.00 & \multirow[t]{2}{*}{68.00} & \multirow[t]{2}{*}{.166} \\
\hline & Kontrol & 14 & 16.64 & 233.00 & & \\
\hline \multirow[t]{2}{*}{ Roller } & Deney & 14 & 23.21 & 185.50 & \multirow[t]{2}{*}{80.00} & \multirow[t]{2}{*}{.404} \\
\hline & Kontrol & 14 & 15.79 & 221.00 & & \\
\hline \multirow{2}{*}{$\begin{array}{l}\text { Duygusal tepki } \\
\text { verebilme }\end{array}$} & Deney & 14 & 12.00 & 168.00 & \multirow[t]{2}{*}{63.00} & \multirow[t]{2}{*}{.101} \\
\hline & Kontrol & 14 & 17.00 & 238.00 & & \\
\hline \multirow{2}{*}{$\begin{array}{l}\text { Gereken } \\
\text { gösterme }\end{array}$} & Deney & 14 & 16.68 & 233.50 & \multirow[t]{2}{*}{67.50} & \multirow[t]{2}{*}{.155} \\
\hline & Kontrol & 14 & 12.32 & 172.50 & & \\
\hline Davranış & Deney & 14 & 14.14 & 198.00 & \multirow[t]{2}{*}{93.00} & \multirow[t]{2}{*}{.817} \\
\hline kontrolü & Kontrol & 14 & 14.86 & 208.00 & & \\
\hline \multirow[t]{2}{*}{ Genel işlevler } & Deney & 14 & 14.29 & 200.00 & \multirow[t]{2}{*}{95.00} & \multirow[t]{2}{*}{.890} \\
\hline & Kontrol & 14 & 14.71 & 206.00 & & \\
\hline
\end{tabular}

Tablo 1'de görüldügü gibi deney ve kontrol gruplarına atanan ebeveynlere uygulanan 'ADÖ’ toplam puanı ve alt ölçekleri öntest puanları arasında anlamlı bir farklılık olmadığı ortaya çıkmıştır. 
Şiddetsiz Karşı Koyma Programının Ebeveynlerin Aile İlişkileri ve Ebeveynlik Algıları Üzerindeki Etkisi

\section{Bulgular}

$\mathrm{Bu}$ araştırmada, şiddet içeren tutum ve davranışlara sahip çocukları olan ebeveynlere uygulanan şiddetsiz karşı koyma programının ebeveynlerin aile etkileşimleri, anne-baba olarak hissettikleri yetersizlik, çaresizlik ve yaşadıkları stres duyguları üzerindeki etkisi incelenmiştir. Araştırmadan elde edilen bulgular denence sırasına uygun olarak aşağıda sunulmuştur.

Denence 1: 'Şiddetsiz Karşı Koyma' programının uygulandiğı deney grubu ebeveynlerinin kontrol grubu ebeveynlerine göre 'Aile Değerlendirme Ölçeği' toplam puanı ve alt ölçeklerinden aldıkları sontest puanları, öntest puanlarından anlamlı düzeyde düşüktür ve bu fark izleme ölçümünde de devam etmektedir.

Araştırmanın birinci denencesini sınamaya yönelik verilerin analizi aşamasında, grupların söz konusu ölçme aracından aldıkları puanların normal dağılım özelliği göstermemesi sebebiyle, parametrik olmayan testlerden biri olan Wilcoxon İşaretli Sıralar Testi uygulanarak deney ve kontrol grubundaki anne-babaların öntest ve sontest puanları arasında anlamlı bir farklı1ık olup olmadığına bakılmıştır. Analiz sürecinde deney ve kontrol grubuna ait veriler ayrı ayrı analiz edilmiş, elde edilen bulgular Tablo 2' de birlikte verilmiştir.

Tablo 2 incelendiğinde deney grubundaki anne-babaların "Aile Değerlendirme Ölçeği” toplam puan ortalamaları: $(Z=-3.240 ; \mathrm{p}<.05)$; Problem çözme $(Z=-3.309 ; \mathrm{p}<.05)$; İletişim: $(\mathrm{Z}=-$ 3.187; $\mathrm{p}<.05)$; Roller: $Z=-3.239 ; \mathrm{p}<.05)$; Duygusal tepki verebilme: $(Z=-2.213 ; \mathrm{p}<.05)$; Davranış kontrolü $(\mathrm{Z}=-3.014 ; \mathrm{P}<.05)$ ve Genel işlevler $(\mathrm{Z}=-3.142 ; \mathrm{P}<.05)$ alt ölçekleri öntest ve sontest puanları arasında anlamlı bir farklılığın olduğu görülürken; gereken ilgiyi gösterme alt ölçeği $(Z=-1.559 ; \mathrm{p}>.05)$ öntest ve sontest puanları arasında ise anlamlı bir farklılığın olmadığı görülmüştür.

Kontrol grubundaki ebeveynlerin puanları incelendiğinde ise öntest ve sontest puan ortalamaları arasında anlamlı bir farklılığın olmadığı (ADÖ Toplam; $Z=-.735 ; p>.05 ;$ Problem çözme: $Z=-303 ; p>.05$; İletişim: $Z=-1.040 ; p>.05)$, Roller: $Z=-.957 ; p>.05$; Duygusal tepki verebilme: $Z=-1.194 ; p>.05$; Gereken ilgiyi gösterme: $Z=-.439 ; p>.05$; Davranış kontrolü: $\mathrm{Z}=-.179 ; \mathrm{p}>.05 ;$ Genel işlevler: $\mathrm{Z}=-1.117 ; \mathrm{p}>.05)$ görülmüştür. $\mathrm{Bu}$ sonuç ile deney grubundaki ebeveynlerin aile değerlendirme ölçeği öntest puanlarının sontest puanlarında düşüş göstermesi dikkate alındığında, uygulanan programın "Aile Değerlendirme Ölçeği”, gereken ilgiyi gösterme alt ölçeği dışında kalan ADÖ toplam puan ve diğer alt ölçekler bakımından ebeveynlerin sağliklı aile ilişkileri ve etkileşim becerileri geliştirmesi üzerinde pozitif yönde anlamlı bir etkisinin olduğu söylenebilir.

Deney grubundaki ebeveynlerin 'Aile Değerlendirme Ölçeği' toplam puanı ve alt ölçeklerinin sontest ve izleme testi ölçümlerinden aldıkları puanlar arasındaki farklılığı sınamak amacıyla yapılan Wilcoxon İşaretli Sıralar Testi analizinden elde edilen sonuçlar Tablo 3' te yer almaktadır. 
Tablo 2. Deney ve Kontrol Grubundaki Ebeveynlerin Aile Değerlendirme Ölçeği Toplam Puanı ve Alt Ölçekleri Öntest ve Sontest Puanlarına İlişkin Wilcoxon İşaretli Sıralar Testi Analiz Sonuçları

\begin{tabular}{|c|c|c|c|c|c|c|}
\hline Gruplar & Sontest-Öntest & $n$ & Stra Ortalamalart & Stra Toplamı & $Z$ & $p$ \\
\hline ADÖ Toplam & Negatif Sira & 13 & 8.00 & 104.00 & \multirow{3}{*}{-3.240} & \multirow{3}{*}{$.001 *$} \\
\hline Puan & Pozitif Sira & 1 & 1.00 & 1.00 & & \\
\hline Deney Grubu & Eşit & 0 & & & & \\
\hline ADÖ Toplam & Negatif Sira & 6 & 9.33 & 56.00 & \multirow{3}{*}{-.735} & \multirow{3}{*}{.462} \\
\hline Puan & Pozitif Sira & 7 & 5.00 & 35.00 & & \\
\hline Kontrol Grubu & Eşit & 1 & & & & \\
\hline Problem çözme & Negatif Sira & 14 & 7.50 & 105.00 & \multirow{3}{*}{-3.309} & \multirow{3}{*}{$.001^{*}$} \\
\hline \multirow[t]{2}{*}{ Deney Grubu } & Pozitif Sıra & 0 & .00 & .00 & & \\
\hline & Eşit & 0 & & & & \\
\hline Problem çözme & Negatif Sira & 5 & 4.00 & 20.00 & \multirow{3}{*}{-.303} & \multirow{3}{*}{.762} \\
\hline \multirow[t]{2}{*}{ Kontrol Grubu } & Pozitif Sira & 4 & 6.25 & 25.00 & & \\
\hline & Eşit & 5 & & & & \\
\hline İletişim & Negatif Sira & 13 & 7.00 & 91.00 & \multirow{3}{*}{-3.187} & \multirow{3}{*}{$.001 *$} \\
\hline \multirow[t]{2}{*}{ Deney Grubu } & Pozitif Sira & 0 & .00 & .00 & & \\
\hline & Eşit & 1 & & & & \\
\hline İletişim & Negatif Sira & 4 & 3.50 & 14.00 & \multirow{3}{*}{-1.040} & \multirow{3}{*}{.298} \\
\hline \multirow[t]{2}{*}{ Kontrol Grubu } & Pozitif Sira & 5 & 6.20 & 31.00 & & \\
\hline & Eşit & 5 & & & & \\
\hline Roller & Negatif Sira & 13 & 8.00 & 104.00 & \multirow{3}{*}{-3.239} & \multirow{3}{*}{$001 *$} \\
\hline \multirow[t]{2}{*}{ Deney Grubu } & Pozitif Sira & 1 & 1.00 & 1.00 & & \\
\hline & Eşit & 0 & & & & \\
\hline Roller & Negatif Sira & 3 & 5.00 & 15.00 & \multirow{3}{*}{-957} & \multirow{3}{*}{.339} \\
\hline Kontrol Grubu & Pozitif Sira & 3 & 2.00 & 6.00 & & \\
\hline & Eşit & 8 & & & & \\
\hline Duygusal tepki & Negatif Sira & 10 & 6.70 & 67.00 & & \\
\hline verebilme & Pozitif Sira & 2 & 5.50 & 11.00 & -2.213 & $.027 *$ \\
\hline Deney Grubu & Eşit & 2 & & & & \\
\hline Duygusal tepki & Negatif Sira & 3 & 2.33 & 7.00 & & \\
\hline verebilme & Pozitif Sıra & 4 & 5.25 & 21.00 & -1.194 & .233 \\
\hline Kontrol Grubu & Eşit & 7 & & & & \\
\hline Gereken ilgiyi & Negatif Sira & 6 & 8.42 & 50.50 & & \\
\hline gösterme & Pozitif Sira & 5 & 3.10 & 15.50 & -1.559 & .119 \\
\hline Deney Grubu & Eşit & 3 & & & & \\
\hline Gereken ilgiyi & Negatif Sira & 4 & 4.13 & 16.50 & & \\
\hline gösterme & Pozitif Sira & 3 & 3.83 & 11.50 & -.439 & .660 \\
\hline Kontrol Grubu & Eşit & 7 & & & & \\
\hline Davranış kontrolü & Negatif Sira & 12 & 7.38 & 88.50 & & \\
\hline Deney Grubu & Pozitif Sira & 1 & 2.50 & 2.50 & -3.014 & $.003 *$ \\
\hline & Eşit & 1 & & & & \\
\hline Davranış kontrolü & Negatif Sira & 5 & 4.80 & 24.00 & & \\
\hline Kontrol Grubu & Pozitif Sura & 4 & 5.25 & 21.00 & -.179 & .858 \\
\hline & Eşit & 5 & & & & \\
\hline Genel işlevler & Negatif Sira & 13 & 7.88 & 102.50 & & \\
\hline Deney Grubu & Pozitif Sura & 1 & 2.50 & 2.50 & -3.142 & $.002 *$ \\
\hline & Eşit & 0 & & & & \\
\hline Genel işlevler & Negatif Sira & 3 & 6.83 & 20.50 & & \\
\hline Kontrol Grubu & Pozitif Sira & 8 & 5.69 & 45.50 & -1.117 & .264 \\
\hline & Eşit & 3 & & & & \\
\hline
\end{tabular}


Şiddetsiz Karşı Koyma Programının Ebeveynlerin Aile İlişkileri ve Ebeveynlik Algıları Üzerindeki Etkisi

Tablo 3. Deney Grubundaki Ebeveynlerin Aile Değerlendirme Ölçeği Toplam Puanı ve Alt Ölçekleri Sontest ve İzleme Testi Puanlarına İlişkin Wilcoxon İşaretli Sıralar Testi Analiz Sonuçları

\begin{tabular}{|c|c|c|c|c|c|c|}
\hline Gruplar & İzleme-Sontest & $\mathrm{n}$ & Sira Ortalamaları & Sira Toplamı & $\mathrm{Z}$ & $\mathrm{p}$ \\
\hline \multirow{3}{*}{$\begin{array}{l}\text { ADÖ } \\
\text { Toplam Puan }\end{array}$} & Negatif Sira & 4 & 8.50 & 34.00 & \multirow{3}{*}{-.089} & \multirow{3}{*}{.929} \\
\hline & Pozitif Sira & 7 & 4.57 & 32.00 & & \\
\hline & Eşit & 3 & & & & \\
\hline \multirow{3}{*}{ Problem çözme } & Negatif Sira & 4 & 7.25 & 29.00 & \multirow{3}{*}{-.794} & \multirow{3}{*}{.427} \\
\hline & Pozitif Sira & 8 & 6.13 & 49.00 & & \\
\hline & Eşit & 2 & & & & \\
\hline \multirow{3}{*}{ İletişim } & Negatif Sira & 6 & 7.08 & 42.50 & \multirow{3}{*}{-.634} & \\
\hline & Pozitif Sıra & 8 & 7.81 & 62.50 & & 526 \\
\hline & Eşit & 0 & & & & $.5 \angle 0$ \\
\hline \multirow{3}{*}{ Roller } & Negatif Sira & 9 & 6.44 & 58.00 & \multirow{3}{*}{-.876} & \multirow{3}{*}{.381} \\
\hline & Pozitif Sira & 4 & 8.25 & 33.00 & & \\
\hline & Eşit & 1 & & & & \\
\hline \multirow{3}{*}{$\begin{array}{l}\text { Duygusal Tepki } \\
\text { Verebilme }\end{array}$} & Negatif Sira & 8 & 6.50 & 52.00 & \multirow{3}{*}{-.458} & \\
\hline & Pozitif Sira & 5 & 7.80 & 39.00 & & \multirow{2}{*}{.647} \\
\hline & Eşit & 1 & & & & \\
\hline \multirow{3}{*}{$\begin{array}{l}\text { Gereken İlgiyi } \\
\text { Gösterme }\end{array}$} & Negatif Sira & 9 & 6.94 & 62.50 & \multirow{3}{*}{-.630} & \multirow{3}{*}{.529} \\
\hline & Pozitif Sira & 5 & 8.50 & 42.50 & & \\
\hline & Eşit & 0 & & & & \\
\hline \multirow{3}{*}{ Davranış Kontrolü } & Negatif Sira & 5 & 6.00 & 30.00 & \multirow{3}{*}{-.272} & \multirow{3}{*}{.786} \\
\hline & Pozitif Sira & 6 & 6.00 & 36.00 & & \\
\hline & Eşit & 3 & & & & \\
\hline \multirow{3}{*}{ Genel İşlevler } & Negatif Sira & 5 & 5.10 & 25.50 & \multirow{3}{*}{-1.063} & \multirow{3}{*}{.288} \\
\hline & Pozitif Sira & 7 & 7.50 & 52.50 & & \\
\hline & Eşit & 2 & & & & \\
\hline
\end{tabular}

Tablo 3 incelendiğinde, deney grubuna katılan ebeveynlerin ADÖ Toplam puan ( $\mathrm{Z}=$ $.089 ; \mathrm{p}>$.05) ve alt ölçekleri (Problem çözme: $Z=-.794 ; \mathrm{p}>.05 ;$ İletişim: $Z=-.634 ; \mathrm{p}>.05$; Roller: $\mathrm{Z}=-.876 ; \mathrm{p}>.05$; Duygusal Tepki verebilme: $\mathrm{Z}=-.458 ; \mathrm{p}>.05$; Gereken İlgiliyi Gösterme: $Z=-.630 ; p>$.05; Davranış Kontrolü: $Z=-.272 ; p>.05$ ve Genel İşlevler: $Z=-.1063$; $\mathrm{p}>.05)$ sontest ve izleme testi puanları arasında anlamlı bir farklılığın olmadığı görülmektedir.

Denence 2: 'Şiddetsiz Karşı Koyma' programının uygulandı̆̆ deney grubu ebeveynlerinin kontrol grubu ebeveynlerine göre 'Öznel Rahatsızlık Birimleri Anketi - Stresle Baş Etme' boyutu sontest ve izleme testi puanlart öntest puanlartndan anlaml düzeyde yüksektir.

Alanyazın incelendiğinde SUDS ölçümü verilerinin nicel olarak analiz edildiği pek çok araştırma olmakla birlikte (Jangir ve Govinda, 2018; Barnette, 2017; Barron, Mitchell, ve Yule, 2017; Re, McConnell, Reidinger, Schweit, Hendron, 2014; Kim, Bae. ve Park, 2008; North, Hill, Aikhuele, ve North, 2008); bazı araştırmlarda ise SUDS verilerinin frekans, yüzdelik eğilimleri ve puan ortalamalarını belirten grafiklerle nitel olarak analiz edildiği (Larson, Cook, 
Fiat, ve Lyon, 2018; Welfare, ve Hollin, 2015; Tarquını, Schmıtt, Tarquinı, Rydberg, Spitz, 2012) görülmüştür. Bu araştırma kapsamında SUDS anketi verilerinin katılımcıların ilgili puanları işaretleme sıklıkları, puan yüzdelikleri ve ölçümler arası eğilimlerinin grafiklerle karşılaştırmalı bir biçimde sunulmasının daha anlaşılır olacağı düşünülmüştür.

Araştırmanın ikinci denencesini sınamak amacıyla katılımcıların öntest, sontest ve izleme ölçümlerindeki puan aralıkları, frekans ve yüzdelikleri incelenmiş veriler aşağıdaki tablo 4 ve şekil 1'de verilmiştir.

Tablo 4. Deney Grubundaki Ebeveynlerin ‘Öznel Rahatsızlık Birimleri Anketi Stresle Baş Etme’ Öntest, Sontest ve İzleme Puanlarına İlişkin Frekans ve Yüzdelik Değerleri

\begin{tabular}{|c|c|c|c|c|c|c|c|}
\hline \multirow[b]{3}{*}{$\begin{array}{l}\text { Derecelendirme } \\
\text { Aralı̆̆ } 1\end{array}$} & \multicolumn{6}{|c|}{ Stresle Baş Etme $(\mathrm{n}=14)$} & \multirow{2}{*}{ İleme } \\
\hline & \multirow[b]{2}{*}{ Puan } & \multicolumn{2}{|c|}{ Öntest } & \multicolumn{2}{|c|}{ Sontest } & \multirow[b]{2}{*}{ f } & \\
\hline & & $\mathbf{f}$ & $\%$ & $\mathbf{f}$ & $\%$ & & $\%$ \\
\hline Puan & 0 & 0,0 & 0,0 & 0,0 & 0,0 & 0,0 & 0,0 \\
\hline & 1 & 1,0 & 7,1 & 0,0 & 0,0 & 0,0 & 0,0 \\
\hline & 2 & 0,0 & 0,0 & 0,0 & 0,0 & 0,0 & 0,0 \\
\hline & 3 & 5,0 & 35,7 & 1,0 & 7,1 & 0,0 & 0,0 \\
\hline & 4 & 2,0 & 14,3 & 1,0 & 7,1 & 1,0 & 7,1 \\
\hline & 5 & 2,0 & 14,3 & 2,0 & 14,3 & 0,0 & 0,0 \\
\hline & 6 & 3,0 & 21,4 & 1,0 & 7,1 & 3,0 & 21,4 \\
\hline & 7 & 0,0 & 0,0 & 0,0 & 0 & 0,0 & 0,0 \\
\hline & 8 & 1,0 & 7,1 & 3,0 & 21,4 & 2,0 & 14,3 \\
\hline & 9 & 0,0 & 0,0 & 4,0 & 28,6 & 6,0 & 42,9 \\
\hline Puan & 10 & 0,0 & 0,0 & 2,0 & 14,3 & 2,0 & 14,3 \\
\hline Toplam & & 14 & 100 & 14 & 100 & 14 & 100 \\
\hline
\end{tabular}

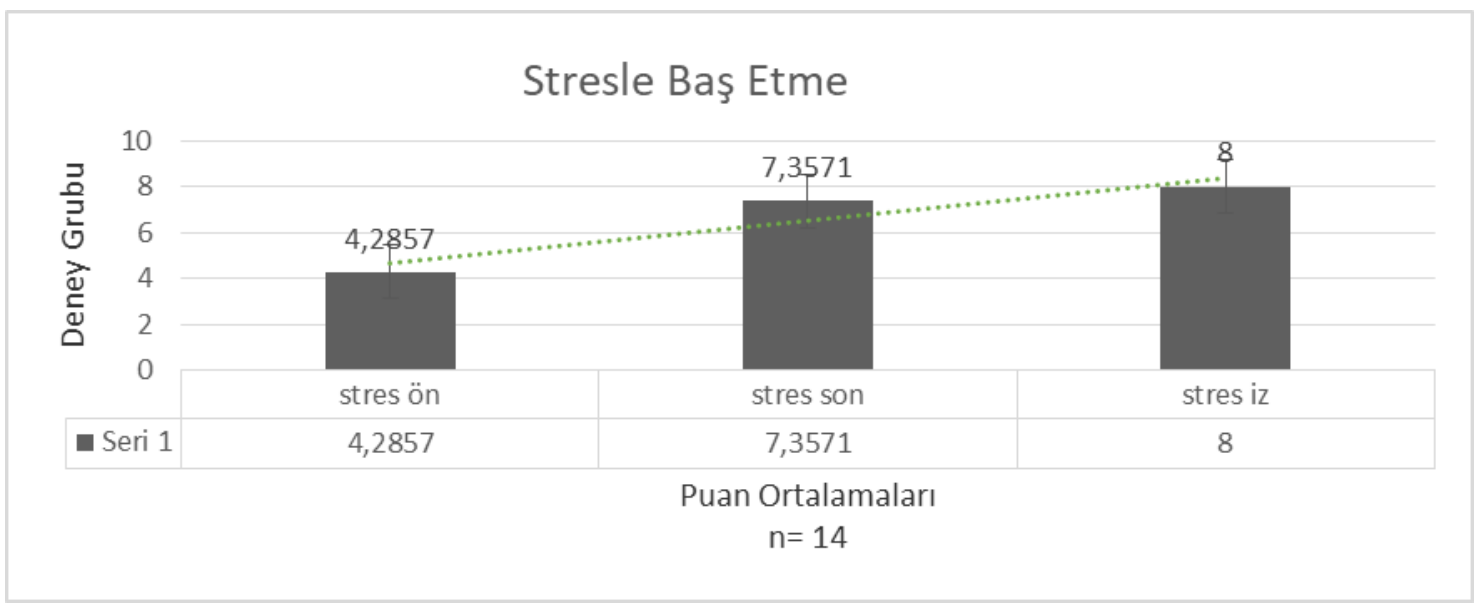

Şekil 1. Katılımcıların Öznel Rahatsızlık Birimleri Anketi Stresle Baş Etme Boyutu Öntest, Sontest ve İzleme Testi Puan Ortalamaları

Tablo 4 incelendiğinde, katılımcıların program öncesi stersle baş etme derecesi algılarına ilişkin frekans ve yüzde değerlerine bakıldığında; program öncesi katılımcıların hiç biri '0', '2', '7', '9' ve '10' değerlerini işaretlemedikleri, öte yandan bir kişinin ' 1 ' değerini (\% $7,1)$, beş kişinin ' 3 ' değerini $(\% 35,7)$, iki kişinin '4' değerini $(\% 14,3)$, iki kişinin ' 5 ' değerini 
Şiddetsiz Karşı Koyma Programının Ebeveynlerin Aile İlişkileri ve Ebeveynlik Algıları Üzerindeki Etkisi

$(\% 14,3)$, üç kişinin ' 6 ' değerini $(\% 21,4)$, ve bir kişinin ' 8 ' değerinin $(7,1)$ işaretlediği görülmüştür.

Sontest verilerine ilişkin katılımcıların işaretlediği değerlere baktı̆̆ımızda; katılımcıların hiç birinin '0', '1', '2' ve '7' değerlerini işaretlemediği, bununla birlikte bir kişinin '32 (\%7,1), bir kişinin ' 4 ' $(\% 7,1)$, iki kişinin ' 5 ' (\%14,3), bir kişinin ' 6 ' $(\% 7,1)$, üç kişinin ' 8 ' $(\% 21,4)$, dört kişinin ' 9 ' $(\% 28,6)$ ve iki kişinin ' 10 ' $(\% 14,3)$ değerini işaretlediği görülmüş̧ür.

Son olarak izleme verilerine ilişkin katılımcıların işaretlediği değerlere baktığımızda; katılımciların hiç birinin '0', '1', '2', '3', '5' ve '7' değerlerini işaretlemediği, bununla birlikte bir kişinin '4' (\%7,1), üç kişinin ' 6 ' (\%21,4), iki kişinin '8' (\%14,3), altı kişinin ' 9 ' (\%42,9), ve iki kişinin ' 10 ' $(\% 14,3)$ değerini işaretlediği görülmüştür. Katılımcıların stresle baş etme becerisi algıları program öncesi ölçümlere göre program sonunda artmış ve uygulamalardan üç ay sonra yapılan izleme ölçümlerinde bu artış düzeyinin korunduğu görülmüştür.

Şekil 1 incelendiğinde ise, deney grubundaki ebeveynlerin öntest puan ortalamalarının $($ Ort. $=4,28)$, sontest puanları (Ort. $=7,35)$ ve izleme testi puanlar ortalamalarında $($ Ort. $=8,00)$ önemli düzeyde artmış olduğu görülmüştür. Bu sonuç ile deney grubundaki ebeveynlerin 'Öznel Rahatsızlık Birimleri Anketi Stresle Baş Etme boyutu' öntest puanlarının sontest ve izleme testinde pozitif yönde artış göstermesi dikkate alındığında, uygulanan programın ebeveynlerin stresle baş etme düzeyleri üzerinde önemli bir etkisinin olduğu söylenebilir.

Denence 3: 'Şiddetsiz Karşı Koyma' programının uygulandiğı deney grubu ebeveynlerinin kontrol grubu ebeveynlerine göre 'Öznel Rahatsizllk Birimleri Anketi Yetersizlikle Baş Etme' boyutu sontest ve izleme testi puanlarl öntest puanlarindan anlamlı düzeyde yüksektir.

Araştırmanın üçüncü denencesini sınamak amacıyla katılımcıların öntest, sontest ve izleme ölçümlerindeki puan aralıkları, frekans ve yüzdelikleri incelenmiş, veriler aşağıdaki tablo 5 ve şekil 2'de verilmiştir. 
Tablo 5. Deney Grubundaki Ebeveynlerin 'Öznel Rahatsızlık Birimleri Anketi Yetersizlikle Baş Etme’ Öntest, Sontest ve İzleme Puanlarına İlişkin Frekans ve Yüzdelik Değerleri

\begin{tabular}{lccccccc}
\hline & \multicolumn{9}{c}{ Yetersizlikle Baş Etme (n= 14) } \\
\hline & \multicolumn{3}{c}{ Öntest } & \multicolumn{2}{c}{ Sontest } & \multicolumn{3}{c}{ İzleme } \\
\hline $\begin{array}{l}\text { Derecelendirme } \\
\text { Aralığ } 1\end{array}$ & Puan & f & $\%$ & f & $\%$ & f & $\%$ \\
\hline Puan & 0 & 0,0 & 0,0 & 0,0 & 0,0 & 0,0 & 0,0 \\
& 1 & 0,0 & 0,0 & 0,0 & 0,0 & 1,0 & 7,1 \\
& 2 & 1,0 & 7,1 & 1,0 & 7,1 & 0,0 & 0,0 \\
& 3 & 1,0 & 7,1 & 0,0 & 0,0 & 1,0 & 7,1 \\
& 4 & 3,0 & 21,4 & 1,0 & 7,1 & 2,0 & 14,3 \\
& 5 & 3,0 & 21,4 & 0,0 & 0,0 & 0,0 & 0,0 \\
& 6 & 3,0 & 21,4 & 1,0 & 7,1 & 1,0 & 7,1 \\
& 7 & 3,0 & 21,4 & 3,0 & 21,4 & 0,0 & 0,0 \\
& 8 & 0,0 & 0,0 & 3,0 & 21,4 & 2,0 & 14,3 \\
Puan & 9 & 0,0 & 0,0 & 2,0 & 14,3 & 6,0 & 42,9 \\
& 10 & 0,0 & 0,0 & 3,0 & 21,4 & 1,0 & 7,1 \\
\hline Toplam & & 14 & 100 & 14 & 100 & 14 & 100 \\
\hline
\end{tabular}

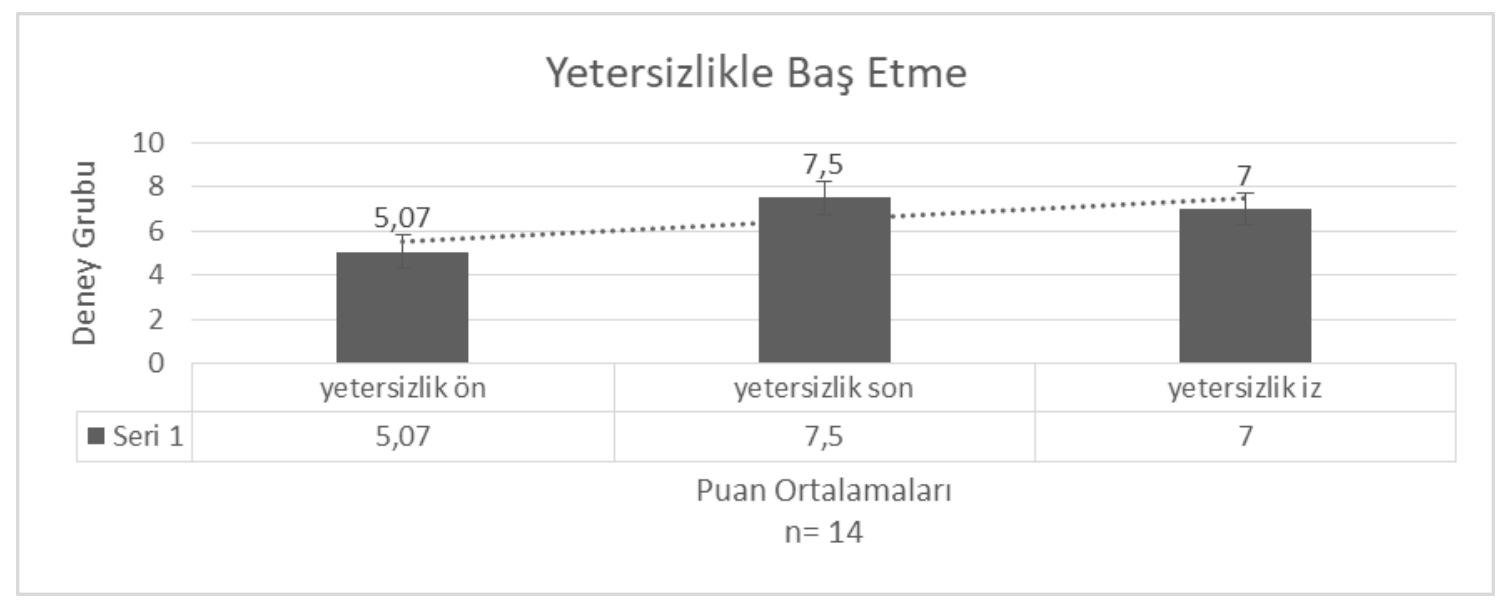

Şekil 2. Katılımcıların Öznel Rahatsızlık Birimleri anketi Yetersizlikle Baş Etme Boyutu Öntest, Sontest ve İzleme Testi Puan Ortalamaları

Tablo 5 incelendiğinde, katılımcıların program öncesi yetersizlikle baş etme düzeyi algılarına ilişkin frekans ve yüzde değerlerine bakıldığında; program öncesi katılımcıların hiç biri ' 0 ', ' 1 ', ' 8 ', '9' ve ' 10 ' değerlerini işaretlemedikleri, öte yandan bir kişinin '2' değerini (\% $7,1)$, bir kişinin ' 3 ' değerini $(\% 7,1)$, üç kişinin ' 4 ' değerini $(\% 21,4)$, üç kişinin ' 5 ' değerini $(\% 21,4)$, üç kişinin ' 6 ' değerini $(\% 21,4)$ ve üç kişinin ' 7 ' değerini $(\% 21,4)$ işaretlediği görülmüştür.

Sontest verilerine ilişkin katılımcıların işaretlediği değerlere baktığımızda; katılımcıların hiç birinin ' 0 ', ' 1 ', ' 3 ' ve ' 5 ' değerlerini işaretlemediği, bununla birlikte bir kişinin ' 2 ' değerini $(\% 7,1)$, bir kişinin ' 4 ' değerini $(\% 7,1)$, bir kişinin ' 6 ' değerini $(\% 7,1)$, üç kişinin ' 7 ' değerini $(\% 21,4)$, üç kişinin ' 8 ' değerini $(\% 21,4)$, iki kişinin ' 9 ' değerini $(\% 14,3)$ ve üç kişinin ' 10 ' değerini $(\% 21,4)$ değerini işaretlediği görülmüştür. 
Şiddetsiz Karşı Koyma Programının Ebeveynlerin Aile İlişkileri ve Ebeveynlik Algıları Üzerindeki Etkisi

Son olarak izleme verilerine ilişkin katılımcıların işaretlediği değerlere baktığımızda; katılımcıların hiç birinin ' 0 ', ' 2 ', ' 5 ' ve '7' değerlerini işaretlemediği, bununla birlikte bir kişinin ' 1 ' değerini $(\% 7,1)$, bir kişinin ' 3 ' değerini (\%7,1), iki kişinin ' 4 ' değerini $(\% 14,3)$, bir kişinin ' 6 ' değerini $(\% 7,1)$, iki kişinin ' 8 ' değerini $(\% 14,3)$ altı kişinin ' 9 ' değerini $(\% 42,9)$ ve bir kişinin ' 1 ' değerini $(\% 7,1)$ işaretlediği görülmüş̧ür. Katılımcıların yetersizlikle baş etme becerisi algıları program öncesi ölçümlere göre program sonunda artmış ve uygulamalardan üç ay sonra yapılan izleme ölçümlerinde bu artış düzeyinin korunduğu görülmüştür.

Şekil 2 incelendiğinde ise, deney grubundaki ebeveynlerin yetersizlikle baş etme öntest puan ortalamalarının (Ort. $=5,07)$, sontest puanları $($ Ort. $=7,50)$ ve izleme testi puanlar ortalamalarında (Ort. $=7,00)$ önemli düzeyde arttığı görülmüştür. Bu sonuç ile deney grubundaki ebeveynlerin 'Öznel Rahatsızlık Birimleri Anketi Yetersizlikle Baş Etme boyutu' öntest puanlarının sontest ve izleme testinde pozitif yönde artış göstermesi, uygulanan programın ebeveynlerin hissettikleri yetersizlik duyguları baş etme düzeyleri üzerinde pozitif yönde önemli bir etkisinin olduğu söylenebilir.

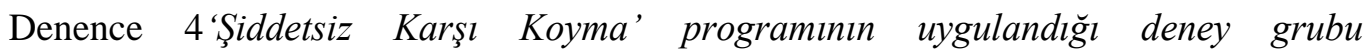
ebeveynlerinin kontrol grubu ebeveynlerine göre 'Ö̈nel Rahatslzlık Birimleri Anketi Çaresizlikle Baş Etme' boyutu sontest ve izleme testi puanlart öntest puanlarından anlaml düzeyde yüksektir.

Araştırmanın dördüncü denencesini sınamak amaciyla katılımcıların öntest, sontest ve izleme ölçümlerindeki puan aralıkları, frekans ve yüzdelikleri incelenmiş, veriler aşağıdaki tablo 6 ve şekil 3'de verilmiştir.

Tablo 6. Deney Grubundaki Ebeveynlerin 'Öznel Rahatsızlık Birimleri Anketi Çaresizlikle Baş Etme’ Boyutu Öntest, Sontest ve İzleme Puanlarına İlişsin Frekans, Yüzdelik Değerleri

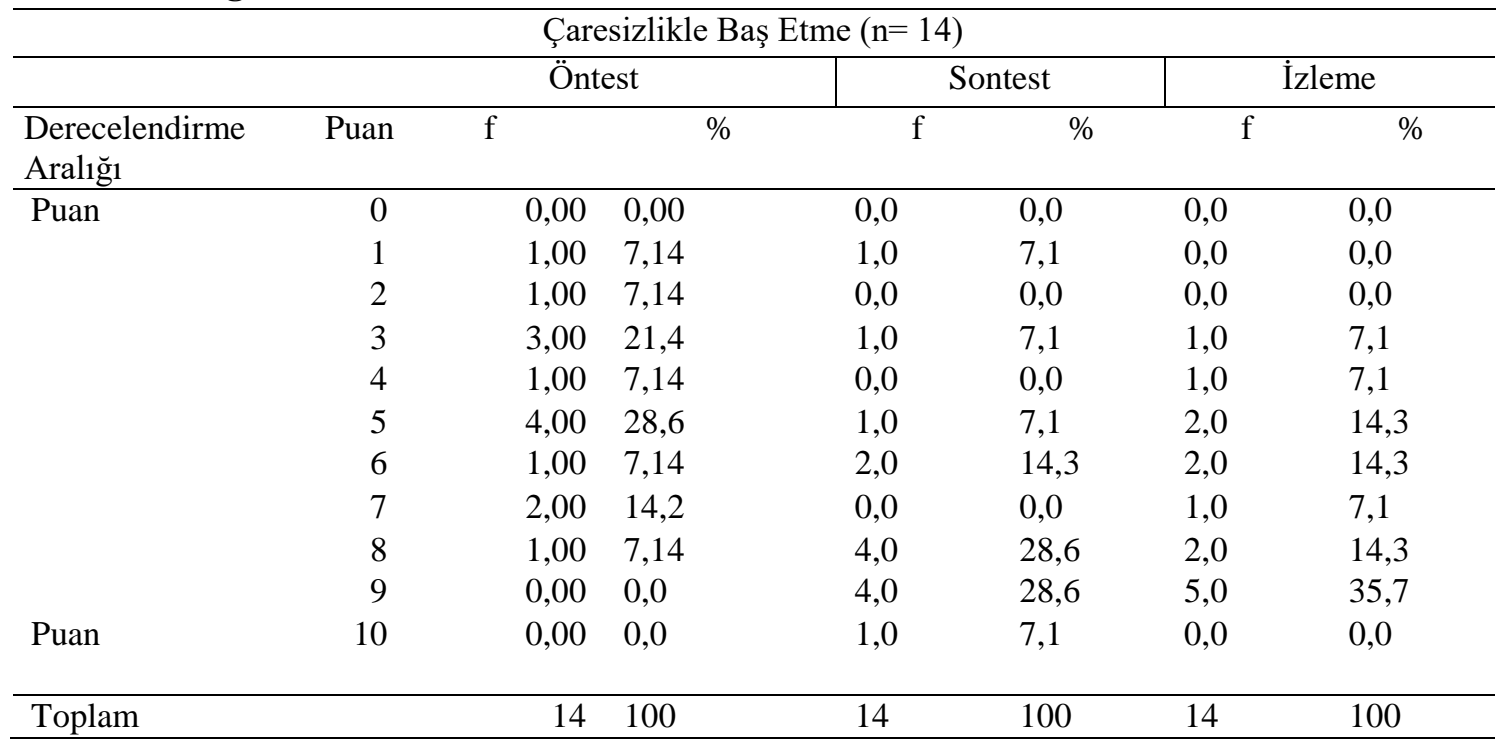




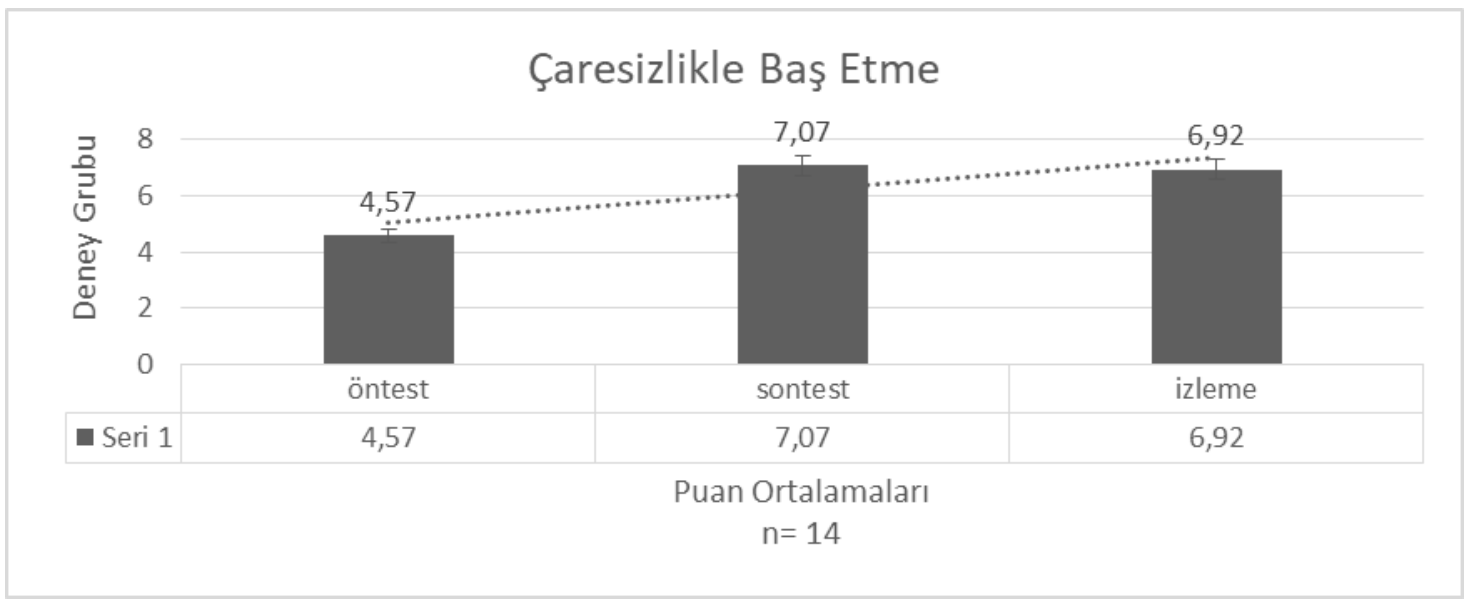
Şekil 3. Katılımcıların Öznel Rahatsızlık Birimleri Çaresizlikle Baş Etme Boyutu Öntest,
Sontest ve İzleme Testi Puan Ortalamaları

Tablo 6 incelendiğinde, katılımcıların program öncesi hissettikleri çaresizlik duyguları ile baş etme düzeyi algılarına ilişkin frekans ve yüzde değerlerine bakıldığında; program öncesi katılımcıların hiçbirinin ' 0 ', ' 9 ' ve ' 10 ' değerlerini işaretlemedikleri, öte yandan bir kişinin ' 1 ' değerini (\% 7,1), bir kişinin ' 2 ' değerini $(\% 7,1)$, üç kişinin ' 3 ' değerini $(\% 21,4)$, bir kişinin ' 4 ' değerini $(\% 7,1)$, dört kişinin ' 5 ' değerini $(\% 28,57)$, bir kişinin ' 6 ' değerini $(\% 7,1)$, iki kişinin '7' değerinin $(\% 14,28)$ ve bir kişinin ' 8 ' değerini $(\% 7,14)$ işaretlediği görülmüştür.

Sontest verilerine ilişkin katılımcıların işaretlediği değerlere baktığımızda; katılımcıların hiç birinin ' 0 ', '2', '4' ve '7' değerlerini işaretlemediği, bununla birlikte bir kişinin ' 1 ' değerini $(\% 7,14)$, bir kişinin ' 3 ' değerini $(\% 7,1)$, bir kişinin ' 5 ' değerini $(\% 7,1)$, iki kişinin ' 6 ' değerini $(\% 14,3)$, dört kişinin ' 8 ' değerini $(\% 28,6)$, dört kişinin ' 9 ' değerini $(\% 28,6)$ ve bir kişinin ' 10 ' değerini $(\% 7,1)$ değerini işaretlediği görülmüştür.

Son olarak izleme verilerine ilişkin katılımcıların işaretlediği değerlere baktığımızda; katılımcıların hiç birinin ' 0 ', ' 1 ', '2' ve ' 10 ' değerlerini işaretlemediği, bununla birlikte bir kişinin ' 3 ' değerini $(\% 7,1)$, bir kişinin ' 4 ' değerini $(\% 7,1)$, iki kişinin ' 5 ' değerini $(\% 14,3)$, iki kişinin ' 6 ' değerini $(\% 14,3)$, bir kişinin ' 7 ' değerini $(\% 7,1)$ iki kişinin ' 8 ' değerini $(\% 14,3)$ ve beş kişinin ' 9 ' değerini $(\% 35,7)$ işaretlediği görülmüştür. Katılımcıların yetersizlikle baş etme becerisi algıları program öncesi ölçümlere göre program sonunda artmış ve uygulamalardan üç ay sonra yapılan izleme ölçümlerinde bu artış düzeyinin korunduğu görülmüştür.

Şekil 3 incelendiğinde ise, deney grubundaki ebeveynlerin yetersizlikle baş etme öntest puan ortalamalarının $($ Ort. $=4,57)$, sontest puan ortalamaları $($ Ort. $=7,00)$ ve izleme testi puan ortalamalarında (Ort. $=6,92$ ) önemli düzeyde arttığı görülmüştür. $\mathrm{Bu}$ sonuç ile deney grubundaki ebeveynlerin 'Öznel Rahatsızlık Birimleri Anketi çaresizlikle baş etme boyutu' öntest puanlarının sontest ve izleme testinde pozitif yönde artış göstermesi dikkate alındığında, uygulanan NVR programının ebeveynlerin hissettikleri çaresizlik duyguları ile baş etme düzeyleri üzerinde pozitif yönde önemli bir etkisinin olduğu söylenebilir.

Araştırma kapsamında kontrol grubuna alınan ebeveynlere herhangi bir işlem uygulanmadığından ‘Aile Değerlendirme Ölçeği ve ‘Öznel Rahatsızlık Birimleri Anketi’ öntest, 
Şiddetsiz Karşı Koyma Programının Ebeveynlerin Aile İlişkileri ve Ebeveynlik Algıları Üzerindeki Etkisi

sontest ve izleme testi ölçümlerinden aldıkları puanlar arasındaki farklılığa bakılmasına gerek görülmemiştir.

\section{Tartışma ve Sonuç}

Araştırma sonuçları incelendiğinde, 'Şiddetsiz Karşı Koyma' ebeveyn programının uygulandığı deney grubu ebeveynlerinin, kontrol grubunda yer alan ebeveynlere kıyasla aile etkileşimi ve ilişkilerinin pozitif yönde geliştiği, ebeveynlerin yetersizlikle baş etme, çaresizlikle baş etme ve stresle baş etme algıları üzerinde anlamlı bir artış olduğu görülmüştür. Bununla birlikte, ebeveynlerin çocuklarına yönelik Aile Değerlendirme Ölçeği Gereken İlgiyi Gösterme alt ölçek puanları üzerinde anlamlı bir farklılaşma görülmemiştir. Bu araştırmanın sonuçları, Türkiye'de ve dünyada ebeveynlere yönelik son yıllarda yapılan bazı benzer deneysel araştırma sonuçlarıyla paralellik göstermektedir (Sanders, 2006; Wilson ve Mark, 2007; Stallman ve Ralph, 2007; Pehlivan, 2008; Weinblatt ve Omer, 2008; Omer, 2011; Omer, Steinmetz, Carthy ve Schlippe, 2013; Newman, Fagan ve Webb, 2014; Lav1-Levav1, Shachar ve Omer, 2013; Kaymak-Özmen,2013; Çekiç, 2015).

Omer, Schorr-Sapir ve Weinblatt (2008), şiddete karşı koymayı amaçlayan çalışmasında, uygulanan NVR programının ebeveyn ve çocuk arasındaki gerginliği azalttığı ve mağdur olan kardeşlere koruma sağladığı bulunmuştur. Bu araştırmada çıkan sonuçlar benzer şekilde ailelerin etkileşim biçimlerine olumlu katkı sağladığı görülürken, ev içinde şiddete maruz kalan diğer çocukların neler yaşadığı konusunda ölçüme dayalı detaylı bilgi toplanmamıştır. Weinblatt ve Omer (2008), tarafindan yapılan benzer bir çalışmada deneysel uygulamalar sonrasında ebeveynlerdeki yalnızlık, çaresizlik ve gerginliği artırıcı davranışların azaldığı, algılanmış sosyal desteğin arttığı ve ebeveynler tarafından değerlendirilen deney grubundaki gençlerin dışa vuran şiddet davranışlarında anlamlı düzeyde azalma olduğu tespit edilmiştir. Bu araştırmada ebeveynlerin yaşadığı çaresizlikle baş etme, yetersizlikle baş etme ve stres ile ile baş etme algılarında olumlu yönde artış olduğu görülmesine rağmen, Türk kültür ve aile yapısının önemli bileşenlerinden olan gizlilik ve aile dışından destek almaya sıcak bakmama anlayışı konusunda süreç içerisinde farklı görüşler ortaya çıkmıştır. Bu anlamda katılımcılar evde neler olduğunu dışarıya paylaşmak konusunda zaman zaman zorlandıklarını belirtmişlerdir. Buna rağmen, NVR programının en önemli iddaalarından birisi olan destek sistemini harekete geçirmek konusunda ebeveynler farklı bir bakış açısı kazandıklarını ve problemlerin nasıl devam ettiğine yönelik farkındalık kazandıklarını belirtmişlerdir.

Newman, Fagan ve Webb (2014), uyguladıkları şiddetsiz karşı koyma ebeveyn programı sonrasında pozitif yönde anlamlı bir farklılıklar bulmuşlardır. Uygulanan NVR programında gerginliğin azaltılması ve koşulsuz sevgi eylemleri ebeveynler tarafindan en faydalı müdahaleler olarak belirlenmiştir. $\mathrm{Bu}$ araştırmada aile etkileşimine dair bulgular ve program süreci içinde ifade edilen katılımcı görüşleri doğrultusunda aile ilişkilerinde ve ev içerisinde gerginliğin azaldığı söylenebilirken, ebeveynlerin çocuklarına yönelik aile değerlendirme ölçeği alt boyutlarından biri olan gereken ilgiyi gösterme alt boyunda anlamlı bir farklılaşma olmadığı görülmüştür. Çocuklarda istenmeyen davranışların ortadan kaldırılması konusunda anne-babaların tutarlı bir ebeveyn yaklaşımı göstermesi çok önemlidir. Aile içi uyum, ailenin çocuğuna karşı gösterdiği tutum ve yaklaşım çocuğun çevresine karşı göstereceği davranışların ve hayata bakış açısının temelini oluşturur (Çağdaş, 2009). Bu çerçevede program 
sonrasında ebeveynlerin aile ilişkileri ölçeği gereken ilgiyi gösterme alt boyutunda anlamlı farklılaşma olmaması, babaların programa katılmaması ve yeterli desteğin annelere verilememesi ile açıklanabilir.

Lavi-Levavi, Shachar ve Omer (2013) tarafından yapılan bir başka çalışmada NVR eğitimine alınan ve yıkıcı davranışlara sahip çocukları olan ebeveynler kontrol grubu ile karşılaştırıldığında, ebeveynlerin yaşadığı çaresizlik duygularında anlamlı iyileşmeler olduğu görülmüştür. $\mathrm{Bu}$ araştırma kapsamında uygulanan program süreci boyunca katılımcılar, çocuklarının göstermekte olduğu şiddet davranışlarına ilişkin en yoğun hissettikleri duyguların çaresizlik ve yetersizlik olduğunu belirtmişlerdir. Elde edilen sonuçlar, araştırmaya katılan deney grubu ebeveynlerinin çaresizlik ve yetersizlik duyguları ile baş etmek konusunda pozitif ve anlamlı düzeyde gelişme kaydettiğini göstermektedir. Bu araştırmada ebeveynlik becerilerine ilişkin anlamlı sonuçlar elde edilirken, çocukların davranışlarında farklılaşma olup olmadığ konusunda doğrudan çocuklardan veri toplanmamıştır. Program çerçevesinde uygulanacak farklı bir ölçme aracı ile ya da farklı plesebo grupları sürece dahil edilerek bu sınırlılık ortadan kaldırılabilir. Program çerçevesinde sunulan grup müdahalelerine ek olarak, ihtiyaç duyan aile üyelerine bireysel psikolojik destekler ve aile danışma hizmetleri de sunularak, ebeveynlerin şiddetle baş etme becerileri ve aile etkileşimlerinin pozitif yönde gelişimi sağlanabilir.

Türkiye'de ise NVR programının etkililiğini sınayan sadece bir deneysel çalışma bulunmaktadır. Kılıçarslan (2016) tarafından yapılmış bu çalışmada saldırganlık problemi olan ergenlere yönelik sistemik psikoterapi yaklaşımına dayalı hazırlanmış şiddet ve saldırganlıkla baş etme programı ve bu gençlerin ebeveynlerine yönelik de NVR programı uygulanmıştır. Bulgular incelendiğinde, ergenler ve onların anne babalarına uygulanan programların ergenlerde görülen saldırgan davranışları azalttığı, ana-babalarının ebeveynlik becerilerini ve aile ilişkilerini geliştirdiği ve anne-baba stres düzeylerini anlamlı derecede düşürdüğü görülmüştür. $\mathrm{Bu}$ araştırmada, farklı bir gelişim dönemi olarak ergenlik dönemine yeni giren ya da girmekte olan ve ortaokul eğitimlerine devam eden, bununla birlikte şiddet davranışları gösteren çocukların ebeveynlerine yönelik şiddetsiz karşı koyma programı uygulanmıştır. Bu sonuçlar ile, 'Şiddetsiz Karşı Koyma' programının Türk kültür ve aile yapısı içinde farklı yaş dilimlerinde bulunan ergenlerin ebeveynlerinde ve aile atmosferine pozitif anlamda sonuçları oluşturduğu söylenebilir.

Çocuk ve ergenler, özellikle de saldırgan davranışların sıkça görüldüğü, bu davranışların bir problem çözme yöntemi olarak kabul edildiği ve desteklendiği bir aile ve kültürel ortamda bulunuyorlarsa, öğrenmiş oldukları bu baş etme yöntemlerinden vazgeçmeleri onları korunaksız ve zayıf hale getirebilmektedir. Öğrencilerin bu davranışlardan vazgeçmeleri için bu davranışların yerine daha yapıcı beceri ve davranışlar koymaları gerekmektedir (Gültekin, 2008).

Sistemik aile terapisi yaklaşımına göre, çocuk ve ergenlerde görülen şiddet ve saldırganlık içeren davranışlar, onların yaşamları süresince aileleri ve özellikle içinde bulundukları sosyo-kültürel yapı içinde edinmiş oldukları baş etme stratejisi olarak değerlendirilmektedir. Sonuç olarak bu araştırmada, Türkiye'de ebeveynlere yönelik yapılan benzer deneysel çalışmalardan farklı olarak sistemik yaklaşıma dayalı 'Şiddetsiz Karşı Koyma Modeli' uygulanmıştır. Bu modelde çocuk ve ergenlerde görülen davranış problemleri kişisel düzeyde patolojiler olarak değil; aile kökeni, aile yapısı, aile ilişkileri ve sosyo-kültürel faktörler 
Şiddetsiz Karşı Koyma Programının Ebeveynlerin Aile İlişkileri ve Ebeveynlik Algıları Üzerindeki Etkisi

ile birlikte ele alınarak çalışılmaktadır. Araştırma kapsamında ebeveynlere uygulanan NVR programının etkili olmasında, uygulanan etkinliklerin çocuklarda görülen saldırgan davranışları azaltmaya yönelik içeriğinin yanı sıra, ebeveynlerin Türk kültür ve geleneklerine uygun olarak aile yapısı ve dinamiğine yönelik hassasiyetleri temel alınarak, aile içi ilişkileri ve etkileşim biçimlerini de kapsayan bütüncül bir bakış açısı ile yapılandırılmış olmasından kaynaklandığı söylenebilir.

$\mathrm{Bu}$ sonuçlardan hareketle şiddet ve saldırgan davranışları olan çocuklara sahip ebeveynlerin hissettikleri çaresizlikle baş etme, yetersizlik ve stres duyguları ile baş etmeyi artırmada, aile içi ilişkileri ve ebeveyn çocuk etkileşim ağını geliştirmede şiddetsiz karşı koyma ebeveyn programının kullanılmasının yararlı olabileceği düşünülmektedir. Türkiye'de ve dünyada en önemli problemler arasında yer alan şiddet içeren tutum ve davranışların azaltılması konusunda çocuk ve ergenlerle çalışırken sorunun çok boyutlu, kapsamlı bir biçimde ele alınması ve özellikle aileler olmak üzere öğretmenler ve idareciler gibi konunun diğer paydaşlarının da sürece dahil edildiği önleyici, koruyucu ve müdahale edici programların geliştirilerek uygulanmasının yararlı olacağı düşünülmektedir.

Araştırmanın sınırlı yönleri dikkate alındığında; program sonrası ölçümlerdeki anlamlı sonuçlar ebeveynlerin çocukları ile ilgili tüm sorunlarının çözüldüğü şeklinde yorumlanamaz. Zira bu programa sadece anneler katılım göstermiştir. Babaların katılmaması ve uzun vadede edinilen becerilerin anne-babanın tutarlı yaklaşımları ile uygulanamaması gibi riskler çocuklarda görülen problem davranışların tekrar ortaya çıkmasına zemin hazırlayabilir. Bu bağlamda bundan sonra yapılacak çalışmalara farklı projeler ile babaların da dahil edilmesinin çok daha yararlı olabileceği söylenebilir.

Şiddet gibi köklü ve zorlayıcı bir problemle çalışırken, bu araştırmada olduğu şekliyle sadece ebeveynler üzerinde odaklanmak yerine, anne-baba programlarına ek olarak bütüncül bakış açısı çerçevesinde çocuk ve ergenlerin de kendi davranışlarını farklılaştırabileceği, ebeveynleri ile olan yapıcı etkileşimlerini geliştirebileceği ek bireysel psikolojik destek hizmetleri önemli katkılar sağlayabilir. Böylece hem problem odaklı, hem de aile etkileşimi odaklı olacak şekilde tüm aile üyelerine katkı sağlanabileceği düşünülebilir.

Buna ek olarak uygulanan programın etkilerinin uzun vadede kalıcı olup olmadığı daha uzun aralıklarda tekrar ölçümler yapılarak test edilebilir. Araştırmada ebeveynlere yönelik öznel bildirim ölçekleri ile veriler toplanmıştır ve ebeveynlerin uygulanan ölçeklere doğru ve yansız bir şekilde cevap verdiği varsayılmıştır. Son olarak araştırmanın çalışma grubu Adana'da bir ortaokulda eğitimine devam eden öğrencilerin ebeveynlerinden oluşmaktadır. Elde edilen bulgular, ancak benzer eğitim ve sosyo-kültürel yapıdaki gruplara genellenebilir.

\section{Teşekkür}

Bu makale 2015-1-TR01-KA101-016961 sözleşme numaralı "Şiddetsiz Karşı Koyma" isimli Erasmus + projesi çerçevesinde yapılan çalışmaların bir ürünüdür ve Türkiye Ulusal Ajansı tarafından desteklenmiştir. Desteklerinden ötürü Türkiye Ulusal Ajansına teşekkürlerimizi sunariz. 


\section{Kaynakça}

Akgün, E. (2008). Anne-çocuk ilişkisini oyunla geliştirme eğitiminin anne-çocuk etkileşim düzeyine etkisi. Yayımlanmamış doktora tezi, Ankara Üniversitesi Eğitim Bilimleri Enstitüsü, Ankara.

Bacioğlu, S.D. (2014). Effectiveness of prevention programs reducing violence and aggression: A metaanalysis study. Turkish Psychological Counseling and Guidance Journal, 5(42), 294-304.

Barnete, T. (2017), "Sensory-Based Group Treatment In Reducing Physically Actıng-Out Behaviors and Perceived Levels Of Distress". Occupational Terapy Doctorate Capstone Projects. 16. htps://encompass.eku.edu/otdcapstones/16.

Barron, I. G., Mitchell, D. \& Yule, W. (2017). Pilot study: RCT of a group-based psycho-social trauma recovery program in secure accommodation in Scotland. Journal of Family Violence. In Press. doi: $10.1007 / \mathrm{s} 10896-017-9921-8$.

Bates JE, Pettit GS, Dodge KA, \& Ridge B.(1998). Interaction of temperamental resistance to control and restrictive parenting in the development of externalizing behavior. Developmental Psychology, 34,982-995.

Baumrind, D. (1991). The influence of parenting style on adolescent competence and substance use. Journal of Early Adolescence, 11(1), 56-95.

Bugental, D. B., Blue, J., \& Cruzcosa, M. (1989). Perceived control over caregiving outcomes: Implications for child abuse. Developmental Psychology, 25(4), 532-539.

Bugental, D. B. , \& Lewis, J. (1998). Interpersonal power repair in response to threats to control from dependent others. In M. Kofta, G. Weary, \& G. Sedek (Eds.), Personal control in action: Cognitive and motivational mechanisms (pp. 341-362). New York: Plenum.

Bulut, I. (1990). Aile değerlendirme ölçeği el kitabı. Ankara: Özgüzeliş Matbaası.

Coogan, D. (2011). Child to parent violence: Challenging perspectives on family violence. Child Care in Practice, 17(4), 347-358.

Cusack, K., \& Spates, C.R. (1999). The cognitive dismantling of eye movement desensitization and reprocessing (EMDR) Treatment of Posttraumatic Stress Disorder (PTSD) Journal of Anxiety Disorders, 13, 1-2, 87-99.

Çağdaş, A. (2009). Anne-baba-çocuk iletişimi. Ankara: Kök Yayıncılık.

Çekiç, A. (2015) Akılcı duygusal davranışçı yaklaşıma dayalı olarak geliştirilen aile ĕgitim programının anne babaların akılcı olmayan inançlarının ve anne babalık streslerinin azaltılması üzerinde etkililiği. Yayınlanmamış Doktora Tezi, Çukurova Üniversitesi, Adana.

Day, E.M. \& Heismann, E. (2010). Non-violent resistance programme: guidelines for parents, care staff and volunteers working with adolescents with violent behaviours. Publisher: Pavilion Publishing (Brighton) Ltd.

Epli-Koç, H. (2013). Ergen-ebeveyn ilişki geliştirme programının ergenlerin algıladıkları ebeveyn kabul/red düzeylerine ve aile işlevlerine etkisi. Yayınlanmamış Doktora Tezi, On Dokuz Mayıs Üniversitesi Eğitim Bilimleri Enstitüsü, Samsun.

Florsheim P, Tolan P, Gorman-Smith D. (1998). Family relationships, parenting practices, the availability of male family members, and the behavior of inner-city boys in single-mother and two-parent families. Child Devolopment, 69, 1437-1447.

Forgatch, M. S. (1991). The clinical science vortex: developing a theory for antisocial behavior. In D. J. Pepler \& K. H. Rubin (Eds.), The development and treatment of childhood aggression (pp. 291315). Hillsdale, NJ: Erllbaum.

Goddard, N., Van Gink, K., Van der Stegen, B., Van Driel, J., \& Cohen, A. P. (2009). "Hit the iron when it is cold": non-violent resistance in an acute psychiatric ward for adolescents. Maandblad Geestelijke Volksgezondheid, 64, 531-539.

Gültekin, F. (2008). The effect of aggression and anger reduce program on level of aggression and anger of middle school students, (Unpublished doctoral dissertation). Hacettepe University, Ankara.

Hassan, S. B., Osman, M. N. and Azarian, Z, S. (2009) Effects of Watching Violence Movies On The Attudes Concerning Aggression Among Middle Schoolboys (13-17 years old) at International Schools In Kuala Lumpur, Malaysia. European Journal of Scientific Research, 38 (1), 141-156.

Heppner, P. P., Wampold, B. E. ve Kivlighan, D. M. (2013). Psikolojik danışmada araştırma yöntemleri (Çev. Ed. D. M. Siyez). Ankara: Mentis Yayınları.

Jakob, P. (2006). Bringing Non-Violent resistance to Britain. Context, 84, 36-38.

Jangir, S.K. and Govinda R. B. (2018). Efficacy of behaviour modification techniques to reduce stage fright: A study. Indian Journal of Positive Psychology, 9(1), 126-129. 

Etkisi

Kabasakal, Z. (2013). The effects of mother education programs on the functionality, anger management and conflict solution levels of families. EgitimArastirmalart-Eurasian Journal of Educational Research, 52, 1-20.

Karasar, N. (2004). Bilimsel Araştırma Yöntemi (13. Baskı). Ankara: Nobel Yayın Dağıtım.

Kazdin, A. E. (1990). Premature termination from treatment among children referred for antisocial behavior. Journal of Child Psychology, 31, 415-425.

Kilıçarslan, S. (2016). Investıgatıng of the effects of psycho-educatıonal programme that is applied to parents and adolescents towards reductıon of aggressive behavior in adolescents. Doctoral Dissertation, Çukurova Üniversity, Adana/Turkey.

Kim,D. Bae H. and Park Y.C. (2008) Validity of the subjective units of disturbance scale in EMDR. Journal of EMDR Practice and Research, 2(1), 57-62.

Kocayürek E, Sümer H. Z. (2009). Baba katılım eğitiminin aile işlevlerine ve ergenlerin akran ilişkilerine etkisi. Eğitimde Kuram ve Uygulama. 5 (1): 3-17.

Kotchick, B. A., Shaffer, A., Dorsey, S., \& Forehand, R. (2004). Parenting antisocial children and adolescents. In M. Hoghughi \& N. Long (Eds.), SAGE handbook of parenting. Newbury Park, CA: Sage Publications.

Larson, M., Cook, C.R., Fiat, A. \& Lyon, A.R. (2018). Stressed teachers don't make good implementers: examining the interplay between stress reduction and intervention fidelity. School Mental Health $10,61-76$.

Lavi-Levavi, I., Shachar, I., \& Omer, H. (2013). Training in nonviolent resistance for parents of violent children: Differences between fathers and mothers. Journal of Systemic Therapies, 32(4), 79-93.

Lebowitz, E. R. (2013). Parent-based treatment for childhood and adolescent OCD. Journal of ObsessiveCompulsive and Related Disorders, 2(4), 425-431.

Lebowitz, E. R., Dolberger, D., Nortov, E., \& Omer, H. (2012). Parent training in non violent resistance for adult entitled dependence. Family Process, 51(1), 1-17.

Lebowitz, E. R., Omer, H., \& Leckman, J. F. (2011). Coercive and disruptive behaviors in pediatric obsessive-compulsive disorder. Depression and Anxiety, 28(10), 899-905.

Levavi, I. (2010). Reducing escalation between parents and children by non-violent resistance: a systemic controlled evaluation. Doctoral dissertation, Tel-Aviv University.

Levendosky AA, Huth-Bocks A, \& Semel MA. (2002). Adolescent peer relationships and mental health functioning in families with domestic violence. Child Adolescents Psychology; 31, 206-218.

McAdams, C.R. \& Lambie, G.W. (2003). A changing profile of aggression in schools: Its impact and implications for school personal. Preventing School Failure, 47(3), 122-130.

McCart, M.R., Priester, P. Davies, W.H., \& Azen, R. (2006) Differential effectiveness of behavioral parent-training and cognitive-behavioral therapy for antisocial youth: a meta-analysis. Journal of Abnormal Child Psychology,34(4), 525-541.

Newman, M., Fagan, C., \& Webb, R. (2014). Innovations in practice: the efficacy of nonviolent resistance groups in treating aggressive and controlling children and young people: a preliminary analysis of pilot NVR groups in Kent. Child and Adolescent Mental Health, 19(2), 138-141.

North, M. M. Hill, J. Aikhuele, A. S. and North, S. M. (2008). Virtual Reality Training in Aid of Communication Apprehension in Classroom Environments. International Journal of Emerging Technologies in Learning (iJET), 3(2), 34-38.

Oleffs, B., von Schlippe, A., Omer, H., \& Kritz, J. (2009). Youngsters with externalizing behavior problems: Effects of parent-training. Familiendynamik, 34, 256-265.

Omer, H. (2000). Parental presence: Reclaiming a leadership role in bringing up our children. Phoenix, AZ, Zeig, Tucker.

Omer, H. (2001) Helping parents deal with children's acute disciplinary problems without escalation: the principle of non-violent resistance. Family Process, 40(1), 53-66.

Omer, H. (2004). Nonviolent resistance: a new approach to violent and self-destructive children. New York: Cambridge University Press.

Omer, H., Irbauch, R., Berger, H., \& Katz-Tissona, R. (2006). Non-violent resistance and school violence. Paper presented at the Mifgash Leavodah Hinukhit Sotzialit, Israel.

Omer, H., Schorr-Sapir, I., and Weinblatt, U. (2008) Non-violent resistance and violence against siblings. Journal of Family Therapy, 30, 450-464.

Omer, H. (2011). The new authority: family, school, community. New York: Cambridge University Press 
Omer, H., \& Dolberger, D.I. (2015). Helping parents cope with suicide threats: An approach based on nonviolent resistance. Family Process. doi: 10.1111/famp.12129.

Omer, H. \& Lebowitz E.R. (2016). Nonviolent resistance: helping caregivers reduce problematic behaviors in children and adolescents. Journal of Marital and Family Therapy, 42(4), 688-700

Omer, H., Irbauch, R., Berger, H., \& Katz-Tissona, R. (2006). Non-violent resistance and school violence. Mifgash Leavodah Hinukhit Sotzialit, Israel.

Omer, H., Steinmetz, S. G., Carthy, T., \& von Schlippe, A. (2013). The anchoring function: Parental authority and the parent-child bond. Family Process, 52(2), 193-206.

Öner, N. (1997). Türkiye'de kullanılan psikolojik testler, bir başvuru kaynăğ (3.Bask1). İstanbul: Boğaziçi Üniversitesi Yayınları.

Patterson, G. R. (1980). Mothers: The unacknowledged victims. Monograph of the Society for Research in Child Development, 186, 1-47.

Pişkin, M. (2010). Examination of peer bullying among primary and middle school children in Ankara. Education and Science, 35(156), 175-189.

Robson, C., (1993). Real world research: a resource for social scientists and practitioner researchers. Blakewell, Cambridge, USA.

Re P, McConnell JW, Reidinger G, Schweit R, Hendron A (2014) Effects of yoga on patients in an adolescent mental health hospital and the relationship between those effects and the patients' sensory-processing patterns, Journal of Child and Adolescent Psychiatric Nursing. 27, 175-82.

Salzinger S, Feldman T, Hood J. (2002). An ecological framework for understanding risk forexposure to community violence and the effects of exposure on children and adolescents. Aggress Violent Beh, 7, 423-451.

Sharp, G. (1973). The politics of nonviolent action. Boston, MA: P. Sargent Publisher.

Shimshoni, Y., Farah, H., Lotan, T., Grimberg, E., Dritter, O., Musicant, O., et al. (2015). Effects of parental vigilant care and feedback on novice driver risk. Journal of Adolescence, 69-80. doi: 10.1016/j.adolescence.2014.11.002 25480357.

Schlippe, A. V. (2006). From family therapy to systemic parental coaching. In C. Tsirigotis, A. von Schlippe, \& J. Schweitzer-Rothers (Eds.), Coaching for parents: Mothers, fathers and their "job" (pp. 44-67). Heidelberg: Carl Auer (in German).

Steinberg, L. (1987). Familial Factors in Delinquency: A Developmental Perspective. Journal of Adolescent Research, 2, (3), 255 - 268.

Steinkellner, H., \& Ofner, S. (2011). The seven pillars of the new authority. In U. E. Gamauf-Eberhardt \&

C. Reumann (Eds.), Meine Schule gegen Gewalt. Friendsburg, Austria: Friedensinstitut Burg Schlaining.

Şahin, F. T. ve Kalburan, N. C. (2009). Aile eğitim programları ve etkililiği: Dünyada neler uygulanıyor? Pamukkale Üniversitesi Eğitim Fakültesi Dergisi, 1 (25), 1-12.

Tarquinıo, C., Schmitt, A., Tarquinıo, P., Et Al. Rydberg, J.-A. Spitz E. (2012). Benefits of 'eye movement desensitization and reprocessing' psychotherapy in the treatment of female victims of intimate partner rape. Sexologies, 21(2), 60-67.

Uzbaş, A. ve Topçu Kabasakal, Z. (2009). İlköğretim okullarında saldırganlık ve şiddet davranışlarının yaygınlı̆̆ı. Ilköğretim Online, 9(1), 93-105.

van Holen, F., Vanderfaeillie, J., \& Omer, H. (2015). Adaptation and evaluation of a nonviolent resistance intervention for foster parents: A progress report. Journal of Marital and Family Therapy. doi: 10.1111 jmft.12125.

Weinblatt, U., \& Omer, H. (2008). Non-violent resistance: A treatment for parents of children with acute behavior parents. Journal of Marital and Family Therapy, 34, 75-92.

Webster-Stratton, C., \& Herbert, M. (1994). Troubled families, problem children. Working with parents: A collaborative process. New York: John Wiley \& Sons.

Welfare, H. R.\& Hollin, C. R. (2015). Childhood and offense-related trauma in young people imprisoned in England and wales for murder and other acts of serious violence: A descriptive study. Journal of Aggression, Maltreatment \& Trauma, 24, 955-969.

Wilson, D., \& Smith, M. (2014). The unmet needs of the child in non-violent resistance: Integrating developmental dyadic-psychotherapy approaches-lessons from working with adoptive families. Context, 132, 22-26.

Wilson, H. (1987). Parental supervision re-examined. British Journal of Criminology, 27, 215-301. 
Şiddetsiz Karşı Koyma Programının Ebeveynlerin Aile İlişkileri ve Ebeveynlik Algıları Üzerindeki Etkisi

\section{Extended Abstract}

\section{Introduction}

In this century, changes in education and technology, multiculturalism and globalization have deeply affected societies and individuals, most notably children and adolescents. Differentiation in socio-cultural structures can cause children and adolescents to develop unhealthy attitudes and behaviors. Children who can not cope with the tensions and conflicts that they experience, sometimes have a tendency to show violent and aggressive attitudes and behaviors. Violence and aggression have become a very serious social problem in Turkey as well as everywhere in the world. There are many programs in Turkey and in the world to cope with violence and aggression in children and adolescents.

Nonviolent Resistance (NVR) is a new educational model that aims to help parents effectively cope with despair, isolation, and mutual interactions which increase the tension with their children. The reason for using NVR with parents of children with violent behavior problems is related to the desperation and inadequacy feelings of parents. Parents of children with serious behavior problems often see themselves as having less power than the children, think nothing will work and feel themselves pre-defeated when it comes to demands or conflicts.

The purpose of this study is to examine the effect of the NVR parental program on parents who have children with aggressive attitudes and behaviors. 'Non Violent Resistance' parental program was applied to the parents participating in the study and the effects of the program on parental relationships and parental stress, helplessness and inadequacy were examined. The following are the developed hypotheses related to the effectiveness of the NVR program based on problem in the study.

\section{Method}

In the study, a quasi-experimental model with the "pretest-posttest control group" which is one of experimental design types was used. The study group of the research consisted of parents of the students who were in secondary school in Adana during the 2016-2017 academic years and had problems with behaviors that included violence and aggression within the school. Within the scope of the project, the necessary permissions were taken to implement the project by communicating with the school administrators and teachers. Evaluation meetings were held with the parents of the students who were directed to the school guidance service by classroom teachers and school administrators due to their unwanted behavior in the school. Because the group training exercises used in this study required continuity, and because only the mothers stated that they could participate in the sessions in a continuous way, impartial assignment by gender was not possible, so the experimental and control groups consisted of the mothers. Some variables such as the level of economic income and the fact that children and parents have not had any psychiatric diagnosis have been controlled.

Of the volunteer parents who participated in the study, 28 parents (14 Experiment-14 Controls) were assigned to the experimental and control groups. The data of the study were obtained through the 'Family Assessment Scale' and 'Subjective Units of Disturbance Scale applied to the parents in the experimental and control groups. These scales were applied to the 
parents of the experimental and control groups as pretest, post-test and follow-up measurements. In this study, 14 sessions Nonviolent Resistance (NVR) program (Day and Heismann (2010) was applied to the experimental group consisting of parents of students with violent and aggressive behaviors.

\section{Results}

When the analysis results were examined, it was seen that the 'Nonviolent Resistance' program had a significant positive effect on parents' total score and some subscales of Family Assessment Device (Problem Solving, Communication, Roles, Emotional Response Ability, Behavior Control and General Functions), although there was no significant difference in the subscale scores of the parents on demonstrating needed attention of parental involvement in family relations. However, it was seen that parents increased levels of their ability to cope with stress, feelings of inadequacy and helplessness they feel towards their children's attitudes and behaviors including violence and aggression and this effect was long-lasting.

\section{Discussion}

When the results of the research were examined, it was found that the parents of the experimental group in the 'Nonviolent Resistance' parent program had a positive increase in the level of parental inadequacy, helplessness and coping with stress, compared with the parents in the control group. Nevertheless, there was no significant difference in the level of parental attention required for their children. It seems that many different family education programs have been implemented in the world and in Turkey for the parents to cope with violent behaviors of their children. The studies that apply NVR Model in Turkey are very limited, but many applications have been made in many different populations abroad. The results of the study are in parallel with some similar experimental studies for parents in Turkey and abroad.

As a result, 'Non Violent Resistance Model' based on systemic psychotherapy approach was applied in this study, unlike experimental studies for parents in Turkey. In this model behavior problems of the children and adolescents are not considered as pathologic at the personal level; they are studied considering family root, family structure, family relations and socio-cultural factors. Violence and aggressive behaviors of the children and adolescents are regarded as a strategy to cope with their families during their lifetime and especially in the cultural structure they are in.

In the context of these conclusions, while working with children and adolescents on the reduction of violent attitudes and behaviors that are among the most important problems in Turkey and in the world, it is considered to be beneficial to develop and implement preventive, protective and intervention programs that include other stakeholders, especially parents, teachers and administrators. In this context, non-violent resistance parent education program, especially focusing on parental competences and family interactions, can be used in addition to existing programs. 